\title{
CARIBIC aircraft measurements of Eyjafjallajökull volcanic clouds in April/May 2010
}

\author{
A. Rauthe-Schöch ${ }^{1}$, A. Weigelt ${ }^{2}$, M. Hermann ${ }^{3}$, B. G. Martinsson $^{4}$, A. K. Baker ${ }^{1}$, K.-P. Heue ${ }^{1}$, \\ C. A. M. Brenninkmeijer ${ }^{1}$, A. Zahn ${ }^{5}$, D. Scharffe ${ }^{1}$, S. Eckhardt ${ }^{6}$, A. Stohl ${ }^{6}$, and P. F. J. van Velthoven \\ ${ }^{1}$ Max Planck Institute for Chemistry, Atmospheric Chemistry, Mainz, Germany \\ ${ }^{2}$ Helmholtz-Zentrum Geesthacht, Institute for Costal Research, Geesthacht, Germany \\ ${ }^{3}$ Leibniz Institute for Tropospheric Research, Leipzig, Germany \\ ${ }^{4}$ Lund University, Division of Nuclear Physics, Lund, Sweden \\ ${ }^{5}$ Karlsruhe Institute of Technology, Institute for Meteorology and Climate Research, Karlsruhe, Germany \\ ${ }^{6}$ Norwegian Institute for Air Research (NILU), Oslo, Norway \\ ${ }^{7}$ Royal Netherlands Meteorological Institute (KNMI), De Bilt, The Netherlands
}

Correspondence to: A. Rauthe-Schöch (armin.rauthe-schoech@mpic.de)

Received: 17 March 2011 - Published in Atmos. Chem. Phys. Discuss.: 15 June 2011

Revised: 10 January 2012 - Accepted: 16 January 2012 - Published: 19 January 2012

\begin{abstract}
The Civil Aircraft for the Regular Investigation of the Atmosphere Based on an Instrument Container (CARIBIC) project investigates physical and chemical processes in the Earth's atmosphere using a Lufthansa Airbus long-distance passenger aircraft. After the beginning of the explosive eruption of the Eyjafjallajökull volcano on Iceland on 14 April 2010, the first CARIBIC volcano-specific measurement flight was carried out over the Baltic Sea and Southern Sweden on 20 April. Two more flights followed: one over Ireland and the Irish Sea on 16 May and the other over the Norwegian Sea on 19 May 2010. During these three special mission flights the CARIBIC container proved its merits as a comprehensive flying laboratory. The elemental composition of particles collected over the Baltic Sea during the first flight (20 April) indicated the presence of volcanic ash. Over Northern Ireland and the Irish Sea (16 May), the DOAS system detected $\mathrm{SO}_{2}$ and $\mathrm{BrO}$ co-located with volcanic ash particles that increased the aerosol optical depth. Over the Norwegian Sea (19 May), the optical particle counter detected a strong increase of particles larger than $400 \mathrm{~nm}$ diameter in a region where ash clouds were predicted by aerosol dispersion models. Aerosol particle samples collected over the Irish Sea and the Norwegian Sea showed large relative enhancements of the elements silicon, iron, titanium and calcium. Non-methane hydrocarbon concentrations in whole air samples collected on 16 and 19 May 2010 showed a pattern of removal of several hydrocarbons that is typical for chlorine chemistry in the volcanic clouds. Compar-
\end{abstract}

isons of measured ash concentrations and simulations with the FLEXPART dispersion model demonstrate the difficulty of detailed volcanic ash dispersion modelling due to the large variability of the volcanic cloud sources, extent and patchiness as well as the thin ash layers formed in the volcanic clouds.

\section{Introduction}

The Eyjafjallajökull volcano (also known as Eyjafjöll or Eyjafjalla volcano) on the southern coast of Iceland $\left(63.62^{\circ} \mathrm{N}\right.$, $19.63^{\circ} \mathrm{W}$ ) has been dormant for nearly two centuries. Previous eruptions occurred around 920, in 1612 or 1613 and in 1821-1823 (Sigmundsson et al., 2010). The explosive part of the recent eruption began on 14 April 2010 and lasted with interruptions until 22 May 2010 (Sigmundsson et al., 2010). The contact of meltwater from the overlying glacier with the hot magma increased the strength and explosivity of the eruption during the first days (phreatomagmatic explosion, Zimanowski et al., 1997, 2003). The high explosive force was accompanied by the production of unusually fine ash particles with samples from the first two days showing $50 \%-70 \%$ of them being smaller than $100 \mu \mathrm{m}$ (Sanderson, 2010; Taddeucci et al., 2011), $20 \%$ being smaller than $10 \mu \mathrm{m}$ and $7 \%$ being smaller than $2.6 \mu \mathrm{m}$ in diameter in ash samples collected close to the volcano (Gíslason and Alfredsson, 2010). The smallest ash particles $(\lesssim 20 \mu \mathrm{m}$ 
diameter) were transported over long distances due to their slow gravitational settling whereas the larger particles fell out closer to the volcano (Ginoux, 2003; Schumann et al., 2011). Eruptions of the Eyjafjallaökull volcano typically produce relatively small volumes of ejected matter on the order of $0.1 \mathrm{~km}^{3}$ (Sturkell et al., 2009). This also applies to the eruption in April/May 2010 (Gudmundsson et al., 2010); hence it was a Volcanic Eruption Index (VEI) 4 eruption (Newhall and Self, 1982; Jenkins, 2010). The eruption strongly affected European aviation through the prevailing weather situation with a high pressure system (anticyclone) south of Iceland both at the surface and at higher levels (Petersen, 2010). The south-eastward propagating winds over Iceland rapidly transported the emitted ash to Central Europe followed by consecutive re-circulation and trapping of the ash over Europe, thus leading to an unprecedented number of flight cancellations (Gertisser, 2010; Flentje et al., 2010).

When the ash clouds from the Eyjafjallajökull volcano reached Central Europe, a large number of stations started immediately measuring different aspects of the diluted volcanic clouds. Lidars and sun photometers were used to measure aerosol optical depth, backscatter ratios and ash mass concentrations over Hamburg, Leipzig, Munich and other EARLINET stations in Germany (Ansmann et al., 2010, 2011; Emeis et al., 2011; Gasteiger et al., 2011; Wiegner et al., 2011), southern Italy (Mona et al., 2011) and over Belsk in Poland (Pietruczuk et al., 2010). The ceilometer network of the German Weather Service measured the backscatter ratios at 36 stations in Germany (Flentje et al., 2010; Emeis et al., 2011). In addition, ozone sondes and in situ measurements taken at the Hohenpeißenberg observatory in Southern Germany, at the environmental research station Schneefernerhaus on the Zugspitze mountain in the German Alps and with an ultralight aircraft over Southern Germany delivered information about the presence, size, concentration and composition of the ash particles (Bukowiecki et al., 2011; Flentje et al., 2010; Emeis et al., 2011; Schäfer et al., 2011). Particle concentrations, size distributions and sulphur dioxide concentrations were also measured at the Swiss research station Jungfraujoch in the Alps (Bukowiecki et al., 2011). The Falcon research aircraft of the German Aerospace Center (DLR) conducted 17 research flights between 19 April and 18 May 2010 measuring the ash concentration, particle size, particle composition and optical properties, as well as concentrations of carbon monoxide $(\mathrm{CO})$, ozone $\left(\mathrm{O}_{3}\right)$ and sulphur dioxide $\left(\mathrm{SO}_{2}\right)$ (Schumann et al., 2011). Also the French Service des Avions Français Instrumentés pour la Recherche en Environnement (SAFIRE) ATR 42 and Falcon20 aircrafts, the British Facility for Airborne Atmospheric Measurements (FAAM) BAe146 and Natural Environment Research Council (NERC) Dornier Do228 aircrafts, the Netherlands National Aerospace Laboratory (NLR) Citation II aircraft, the Swiss METAIR Dimona motor glider, the Spanish CASA 212 aircraft and a number of smaller aeroplanes con- ducted measurement flights over Europe during the 2010 Eyjafjallajökull eruption. Microwave weather radars were used as well to study the eruption (Marzano et al., 2011).

The Civil Aircraft for the Regular Investigation of the Atmosphere Based on an Instrument Container (CARIBIC) project investigates the physical and chemical processes in the Earth's atmosphere using a Lufthansa Airbus A340-600 long-distance passenger aircraft in scheduled air service. This aircraft is equipped with a purpose-designed inlet system which is permanently mounted at the lower aircraft fuselage and which has sampling probes for trace gases, water vapour, total water and aerosol particles (Brenninkmeijer et al., 2007). In addition, the inlet system houses three miniature telescopes of a multi-axis differential optical absorption spectrometer (MAX-DOAS) system and a forward looking video camera. During routine operations, the CARIBIC container is installed once per month into the forward cargo compartment of the aircraft where it is connected to the inlet system. It then takes measurements during four consecutive routine passenger flights of the aircraft. Lufthansa has been supporting the CARIBIC project since 2004. Between May 2005 and December 2011, more than 260 measurement flights were carried out with the CARIBIC container (see http://www.caribic-atmospheric.com/). The original suite of instruments onboard the CARIBIC container has been described in detail by Brenninkmeijer et al. (2007), but has been upgraded since then (see Sect. 2).

CARIBIC has already measured effects of volcanic eruptions on atmospheric trace gases and aerosols on previous occasions. For instance, after the Kasatochi volcano erupted in 2008, clouds of $\mathrm{SO}_{2}$ were found over Europe (Heue et al., 2010) and the change in elemental composition of lower stratospheric aerosol particles before and after this eruption was analysed (Martinsson et al., 2009).

The most relevant instruments for the investigation of the 2010 Eyjafjallajökull volcanic clouds are the new optical particle counter (OPC) briefly described here in Sect. 2.2, the particle sampler (Nguyen et al., 2006), the improved MAX-DOAS system for remote detection of trace gases (Dix et al., 2009) and the whole air sampler (Brenninkmeijer et al., 2007). The air samples are analysed after each flight sequence in the laboratory for greenhouse gases (Schuck et al., 2009) and a suite of non-methane hydrocarbons (Baker et al., 2010) and halocarbons (O'Sullivan, 2007).

Directly after the first closure of the air space above Germany, Lufthansa approached the CARIBIC team with the suggestion for a special volcano flight mission as information about the ash clouds was scarce. With a lead time of only two days, the CARIBIC measurement container was prepared for the first CARIBIC volcano mission, which took place over Northern Germany, the Baltic Sea and Southern Sweden on 20 April 2010. Two further volcano flights followed: one on 16 May over Ireland and the Irish Sea and the other on 19 May over the Norwegian Sea (Fig. 1). 
The immediate goal of these special measurement flights was to collect as much information as possible regarding the number, size and concentration of the ash particles as well as their composition. The main hazard from volcanic ash clouds to jet aircraft arises from the high temperatures inside aircraft turbines which lead to melting of glassy volcanic particles. The melted ash can cover parts of the inside of the turbines and lead to a loss of power or even flame-out of the engines. The sharp volcanic ash particles combined with the high air speed of jet aircraft can lead to sand-blasting of the cockpit windows and even to completely opaque windows (e.g. Casadevall, 1993; Prata and Tupper, 2009). The ash particles can also clog aircraft openings like pitot tubes, corrupting speed and pressure readings, or air filters. In severe cases, corrosion by volcanic sulphuric acid can inflict damage to the aircraft fuselage and turbines (Casadevall, 1993). Assessment of such hazards and ultimately decisions about the closure of air space therefore require detailed knowledge of the ash cloud's composition, particle sizes and mass concentrations.

This paper discusses the results from the three special mission CARIBIC volcano flights. It starts with an overview of the instruments inside the CARIBIC measurement container in Sect. 2, including a description of the new OPC deployed for the first time during the CARIBIC volcano measurement flights. The three flights are described in Sect. 3 while Sect. 4 summarises the results from the flights. Comparisons of the CARIBIC ash measurements with predictions from the NILU FLEXPART model are presented in Sect. 5. The different aspects of the measurement results from the CARIBIC volcano flights are discussed in Sect. 6. A short summary of this study is given in Sect. 7 .

\section{CARIBIC instruments}

This section introduces the different instruments used to characterise the volcanic clouds encountered during the three CARIBIC Eyjafjallajökull flights. For a comprehensive overview of all instruments onboard the CARIBIC container, the reader is referred to Brenninkmeijer et al. (2007).

\subsection{Aerosol particle inlet system}

Ideally, measurements of micrometer-size particles or larger is carried out using wing-mounted free stream instruments. However mounting such large instruments on a commercial aircraft is not feasible. Consequently, the CARIBIC particle detection and sampling uses air collected via an aerosol inlet probe which consists of a diffuser tube fitted with a leading shroud. The air is transferred to the instruments in the container via 3.5-4.0 m long electropolished stainless steel tubing (Brenninkmeijer et al., 2007). Just upstream the aerosol instruments, after $3.2 \mathrm{~m}$ sampling line, a flow splitter removes the outer $20 \%$ of the sampling volume flow, and only the inner $80 \%$ (core flow) are used for the measurements. Thus the sampling line efficiency up to the flow splitter increases to more than $90 \%$ for particles larger than about $10 \mathrm{~nm}$ diameter, based on theoretical considerations. The particle losses in the individual sampling line sections downstream the flow splitter were calculated and corrected for using empirical equations (Kulkarni et al., 2011). In a similar manner, artifacts due to ash particle break-up at the inlet tip are reduced. The majority of artificial break-up particles should stay close to the inlet walls and for the measurements only the core flow at the centre line (less than $1 \%$ of the air entering the shroud) is used. However, recent studies indicated that (ice) particles hitting instruments or inlet tip surfaces can travel up to several centimetres in the direction perpendicular to the main flow direction (Korolev et al., 2011). Thus, biases in the size distribution measured by CARIBIC inside the volcano cloud are reduced, but can not be totally excluded or quantified. The CARIBIC aerosol inlet has a high particle transmission efficiency for the sub-micrometer particles, but for the super-micrometer particles, the transmission efficiency decreases. Based on empirical equations and experience with other inlet systems, an inlet transmission efficiency was estimated. It is above $60 \%$ for particles smaller than $\sim 5 \mu \mathrm{m}$, but decreases strongly down to zero at about $10 \mu \mathrm{m}$. This inlet transmission efficiency is taken into account in the OPC measurements and in the extrapolation of the particle size distribution below, but nevertheless leads to uncertainty in the measured particle concentrations.

\subsection{The new CARIBIC optical particle counter}

During the CARIBIC container upgrade in autumn 2009, a new optical particle counter (OPC) was constructed by the Leibniz Institute for Tropospheric Research (IfT, Leipzig) to measure the sub-micrometre aerosol particle size distribution. This OPC was flown for the first time during the CARIBIC volcano flights. A detailed description of the new OPC will be published by Weigelt (2012). The following section contains a short overview of the instrument, its characteristics and the OPC data analysis.

The small, lightweight and very robust KS-93 OPC from RION Co., Ltd. (Japan) was chosen as basis instrument for the CARIBIC OPC unit. Housed inside a $19^{\prime \prime} 5 \mathrm{U}$ (221 mm height) rack unit, a computer controlled gas flow system with two mass flow controllers (MKS, Germany) and a fully automated data acquisition (PXI, National Instruments) were arranged around the KS-93. To reduce errors in particle size classification due to laser field inhomogeneities, the measurement air is focused to the centre of the optics by sheathing the measurement air with particle-free air just upstream $(10 \mathrm{~cm})$ of the optics. This sheath air is filtered air drawn in from inside the CARIBIC container. Sensitivity studies indicated the best signal to noise ratio for a sheath air to measurement air ratio of 9:1. 

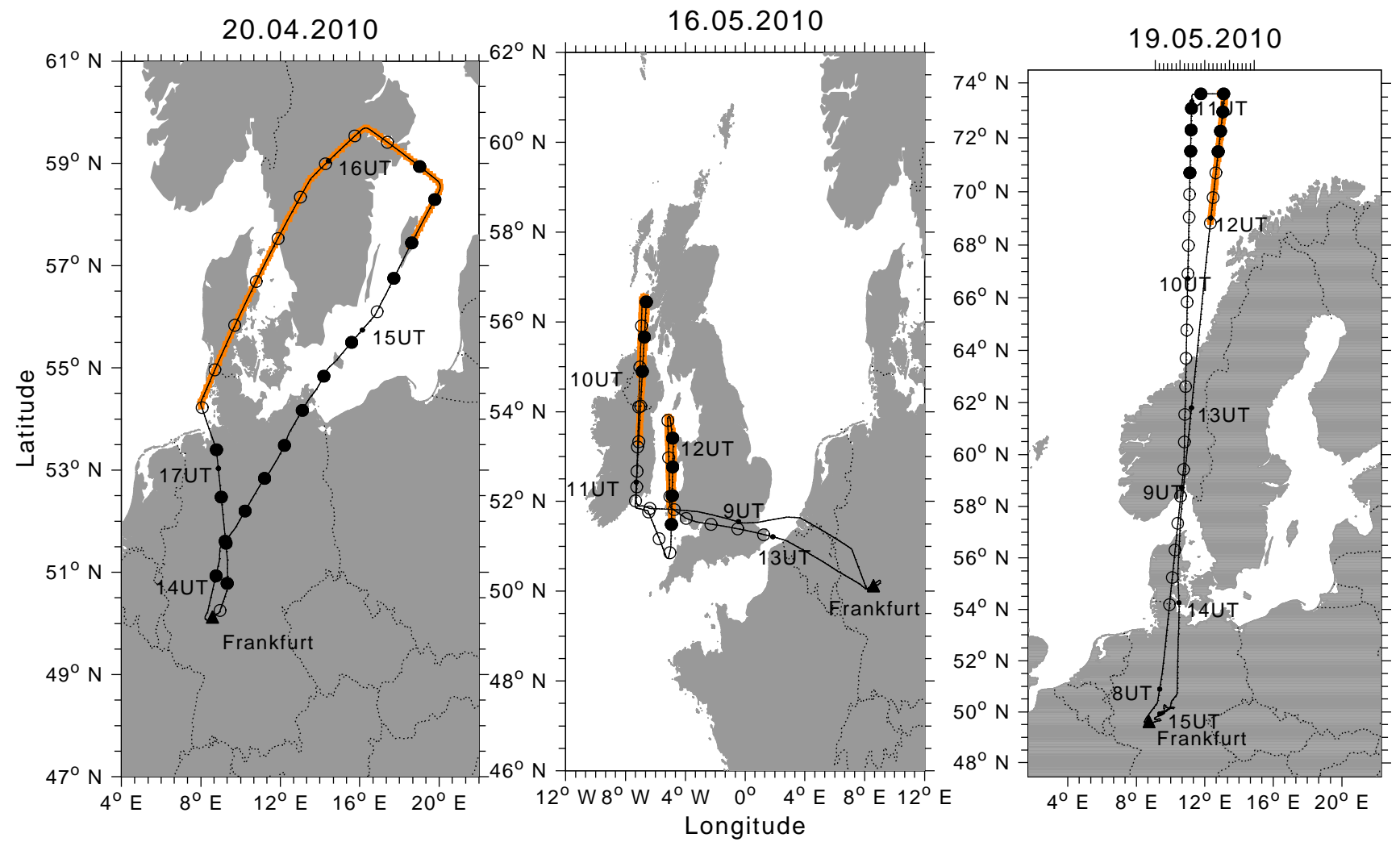

Fig. 1. Flight tracks of the CARIBIC flights on 20 April 2010 (left), 16 May 2010 (middle) and 19 May 2010 (right) with indicated flight times. Circles mark the whole air glass flask sample locations where solid circles denote those samples that have a volcanic influence (as determined from the whole air samples and the backward trajectories). The orange highlighted segments of the flight tracks mark the integration times of those aerosol impactor samples which indicated volcanic origin of the sampled particles. Note the different geographical projection of the right map.

Table 1. Complex refractive index and density for an internal mixture of aerosol particles, based on volume mixing rules. The given volume fractions assume "typical" aerosol composition for those atmospheric regions where most of the CARIBIC measurements were conducted. The refractive indices for the different aerosol compounds are taken from Toon et al. (1976), Hummel et al. (1988), Krekov (1993), Bond and Bergstrom (2006) and Dick et al. (2007). Mixed complex refractive index and particle density are calculated using volume mixing rules.

\begin{tabular}{|c|c|c|c|c|}
\hline \multirow{4}{*}{$\begin{array}{l}\text { Region } \\
\text { Mid-latitude } \\
\text { lowermost } \\
\text { stratosphere } \\
\text { (LMS) }\end{array}$} & \multicolumn{2}{|c|}{$\begin{array}{c}\text { Composition } \\
\text { [volume fraction] }\end{array}$} & \multirow[t]{2}{*}{$\begin{array}{l}\text { Mixed complex } \\
\text { refractive index }\end{array}$} & \multirow[t]{2}{*}{$\begin{array}{l}\text { Mixed particle } \\
\text { density }\left[\mathrm{gcm}^{-3}\right]\end{array}$} \\
\hline & $\mathrm{H}_{2} \mathrm{SO}_{4}$ : & $90 \%$ & & \\
\hline & Organics : & $10 \%$ & \multirow[t]{2}{*}{$\mathrm{n}_{\mathrm{c}, \text { total }}=1.43-0.0001 \mathrm{i}$} & \multirow[t]{2}{*}{$\rho=1.64$} \\
\hline & $\left(\mathrm{NH}_{4}\right)_{2} \mathrm{SO}_{4}:$ & $\begin{array}{l}0 \% \\
0 \%\end{array}$ & & \\
\hline \multirow{5}{*}{$\begin{array}{l}\text { Mid-latitude } \\
\text { upper troposphere } \\
\text { (UT) }\end{array}$} & & & \multirow{5}{*}{$\mathrm{n}_{\mathrm{c}, \text { total }}=1.48-0.0143 \mathrm{i}$} & \multirow{5}{*}{$\rho=1.72$} \\
\hline & $\mathrm{H}_{2} \mathrm{SO}_{4}:$ & $44 \%$ & & \\
\hline & Organics: & $10 \%$ & & \\
\hline & $\left(\mathrm{NH}_{4}\right)_{2} \mathrm{SO}_{4}:$ & $44 \%$ & & \\
\hline & Soot: & $2 \%$ & & \\
\hline \multirow{4}{*}{$\begin{array}{l}\text { Tropical middle } \\
\text { troposphere (MT) }\end{array}$} & $\mathrm{H}_{2} \mathrm{SO}_{4}$ : & $19 \%$ & \multirow{4}{*}{$\mathrm{n}_{\mathrm{c}, \text { total }}=1.48-0.0075 \mathrm{i}$} & \multirow{4}{*}{$\rho=1.63$} \\
\hline & Organics: & $40 \%$ & & \\
\hline & $\left(\mathrm{NH}_{4}\right)_{2} \mathrm{SO}_{4}:$ & $40 \%$ & & \\
\hline & Soot: & $1 \%$ & & \\
\hline
\end{tabular}


To avoid contamination by strongly polluted air around the airport, the OPC unit is set into stand-by mode by the CARIBIC master computer during takeoff and landing. In this stand-by mode the tubes inside the OPC unit are flushed with filtered air provided by a small diaphragm pump. When the aircraft reaches a pressure altitude of $700 \mathrm{hPa}$, the CARIBIC master computer sets the OPC unit into measurement mode. In this mode $15 \mathrm{~cm}^{3}$ min-1 of measurement air and $135 \mathrm{~cm}^{3} \mathrm{~min}-1$ of sheath air are drawn through the KS-93 optics. The pressure inside the measurement cells changes with ambient pressure, but tests have shown that the KS-93 response is very stable in a wide pressure range of $200 \mathrm{hPa}-1000 \mathrm{hPa}$. The signal of the KS-93, laser diode light $(\lambda=830 \mathrm{~nm})$ scattered by the aerosol particles, is recorded with very high frequency $(333 \mathrm{kHz})$ using a realtime PXI system from National Instruments, which allows to analyse even the form of individual particle pulses. Furthermore, the time resolution for the particle size distribution can be varied and chosen case-by-case during data analysis. For statistical reasons, three minutes are used in this study. All other data needed to calculate the particle concentration (volume flow, pressures and temperatures) are recorded with $10 \mathrm{~Hz}$ resolution.

For calibration of the OPC unit different kinds of aerosols encountered in the various CARIBIC flight regions have to be considered. Depending on their refractive indices, particles of identical particle diameter and shape cause different scattering signals. At mid-latitudes the CARIBIC aircraft flies quite often in lowermost stratospheric air (van Velthoven, 2012). For such air masses the particle composition is dominated by sulphuric acid (Murphy et al., 2007). In contrast, in the mid-latitude upper troposphere (UT) and tropical middle troposphere (MT), besides sulphuric acid, also ammonium sulphate, different organics (organic carbon), as well as soot (elemental carbon) become important (Dibb et al., 1999; Kojima et al., 2004; Schwarz et al., 2006; Froyd et al., 2009; Morgan et al., 2009; Pratt and Prather, 2010; Schwarz et al., 2010). Upper tropospheric particles are usually dominated by sulphurous and carbonaceous material (Nguyen et al., 2008; Martinsson et al., 2009).

To obtain a uniform and consistent OPC data analysis for the normal CARIBIC flights, a refractive index sensitivity study was carried out using three internal mixed aerosols representative of (a) the mid-latitude lowermost stratosphere (LMS), (b) the mid-latitude UT and (c) the tropical MT (Table 1). Using volume mixing rules for particle refractive index and density as well as a Mie scattering code for spherical particles, the OPC response curve was calculated for each of the three characteristic aerosol compositions. As an example, Fig. 2a shows the calibration curve obtained from laboratory measurement with latex and ammonium sulfate and transferred to the refractive index of midlatitude upper tropospheric (UT) aerosol particles $(n=1.48$ $0.0143 i$, see Table 1) using a Mie scattering program. Using the three calibration curves and measured particle size distri- butions from a CARIBIC flight on 14 November 2010 from Frankfurt (Germany) to Johannesburg (South Africa), covering all three regions of interest, the total particle mass for each three minute measurement interval was calculated. On average, the derived total particle mass for the mid-latitude LMS aerosol calibration was $10.5 \%$ lower and for the tropical MT aerosol calibration $8.3 \%$ higher than the mass obtained from the mid-latitude UT aerosol calibration. Consequently, the systematic uncertainty of the average particle masses derived by using the CARIBIC OPC size distributions with one fixed average refractive index for all flight regions is in the order of $\pm 10 \%$. Depending on the exact type of aerosol present, the error for single measurements may be larger.

After implementing the sheath air technique, the maximum counting efficiency of the OPC unit increased from $\sim 50 \%$ (manufacturer value) to $\sim 89 \%$ (see Fig 2 b). The relatively large error bars represent mainly the volume flow uncertainties, as the OPC volume flow is obtained by subtracting two roughly equal mass flow controller readings. Like for the size calibration, all calibration points were transferred to mid-latitude UT aerosol.

For the special case of the Eyjafjallajökull volcanic ash particles, a separate calibration has been performed. Following Schumann et al. (2011), Bukowiecki et al. (2011), Kandler (personal communication, 2011) and Shoji et al. (1994), the OPC analysis was repeated with refractive indices of $n=1.50-0.01 \mathrm{i}, n=1.55-0.001 \mathrm{i}$ and $n=1.60-0.0001 \mathrm{i}$ at the OPC wavelength of $830 \mathrm{~nm}$. These values span the range of refractive indices that have been reported for ash from the Eyjafjallajökull (e.g. Schumann et al., 2011). The unknown refractive index is a major source of uncertainty in deriving ash particle masses from the OPC measurements but there are other potentially even larger sources of uncertainty as discussed below. The ash particle density was assumed to be $\rho=2.65 \mathrm{~g} \mathrm{~cm}^{-3}$. Particle aggregates may have a lower density which would directly influence the derived ash particle mass concentrations. Because most volcano flight measurements were obtained at altitudes lower than the normal CARIBIC cruise altitudes, all data outside the ash clouds were analysed using the ammonium sulphate calibration $\left(n=1.52-1.41 \times 10^{-7} \mathrm{i}, \rho=1.83 \mathrm{gcm}^{-3}\right)$. Furthermore, due to the different refractive indices in combination with saturation of the OPC photodiode, the upper detection limit is particle material dependent. For the midlatitude UT aerosol, the ammonium sulphate aerosol and the three volcanic ash refractive indices, the upper detection limits in terms of particle diameter are $1.31 \mu \mathrm{m}, 1.09 \mu \mathrm{m}$ and $1.21 / 1.03 / 0.94 \mu \mathrm{m}$, respectively. For the volcanic ash calibrations, the upper detection limit of the OPC decreases with increasing real part (decreasing imaginary part) of the refractive index. All particle diameters measured by the OPC are derived from the amount of light scattered by the particle using Mie theory and assuming a spherical shape of the particles. The $50 \%$ lower detection limit is calculated 

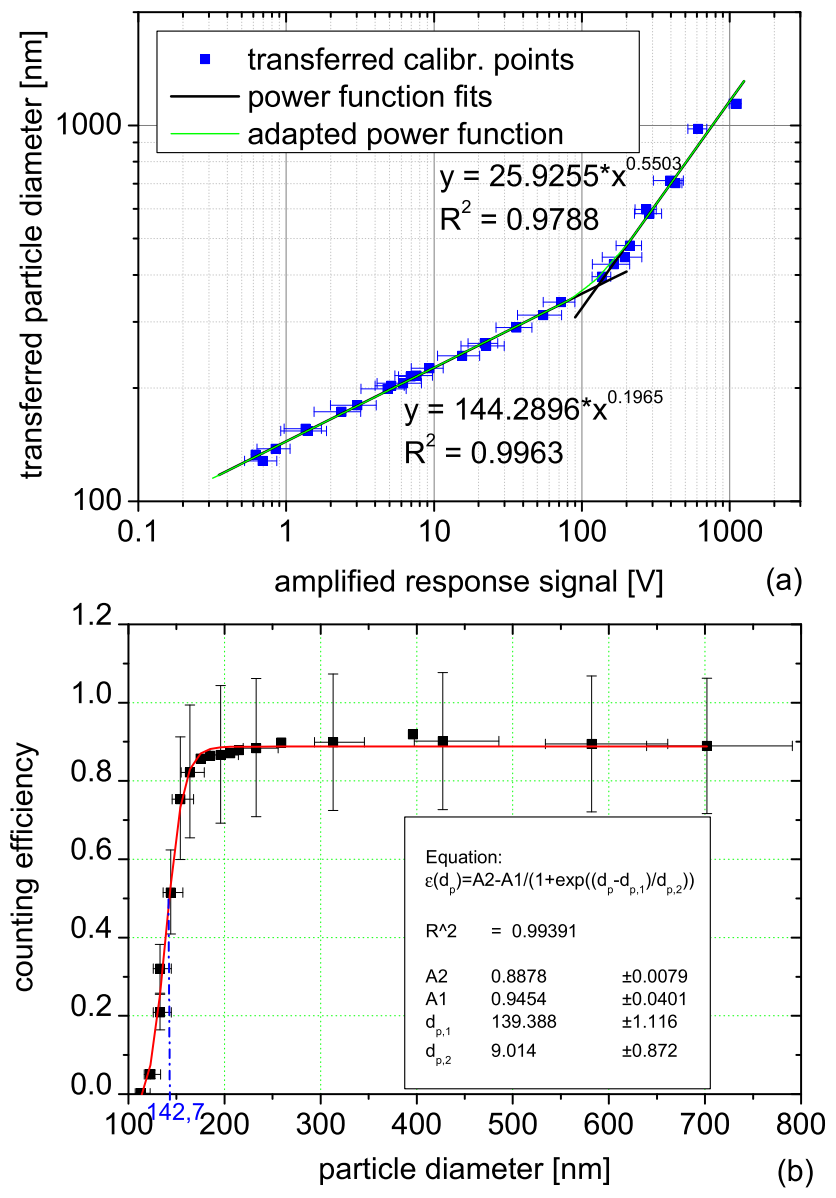

Fig. 2. OPC size calibration (left panel) and counting efficiency (right panel) obtained from laboratory measurements with latex and ammonium sulfate. All calibration points were transferred to the refractive index of mid-latitude upper tropospheric (UT) aerosol particles $(n=1.48-0.0143 \mathrm{i}$, see Table 1$)$ using a Mie scattering program. The adapted fit function (green) is a combination of the two power function fits.

to be $143 \mathrm{~nm}, 139 \mathrm{~nm}$ and $139 / 138 / 137.4 \mathrm{~nm}$ in diameter for mid-latitude UT aerosol, ammonium sulphate and the three refractive indices of volcanic ash, respectively. Consequently, the differences in the response of the CARIBIC OPC to the particles inside and outside the volcano clouds are quite small simplifying the analysis and interpretation of the OPC measurements.

Even if the uppermost OPC size channel has a nominal upper diameter size limit of $0.94-1.21 \mu \mathrm{m}$ for volcanic ash, larger ash particles are still counted in that size channel but their size cannot be resolved. On routine CARIBIC flights, this is not a problem as the air at cruising altitude contains only very few of these coarse mode particles (diameter $>1 \mu \mathrm{m}$ ). In the volcanic ash clouds however, the particle size distribution is enhanced in this size range and these particles contribute significantly to the total ash mass (Schumann

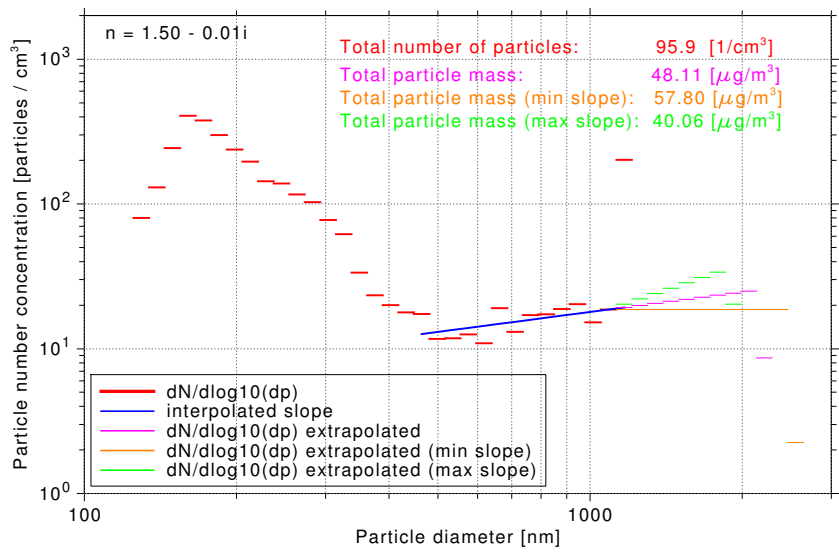

Fig. 3. Example for the extrapolation procedure described in Sect. 2.2 for an OPC measurement inside the volcanic cloud on 19 May $201011: 14$ UTC and a refractive index of $n=1.50-0.01$ i. The red bars show the measured size distribution. The blue line shows the linear fit for particles $>450 \mu \mathrm{m}$ while the magenta bars show the extrapolated "virtual size" channels. The orange and green bars show the extrapolated size distribution using the minimum and maximum slope as determined from all measured ash size distributions (see Sect. 4.3).

et al., 2011; Stohl et al., 2011; Bukowiecki et al., 2011). To account for these large particles the individual particle number size distributions were fitted for diameters $>450 \mathrm{~nm}$ (but excluding the uppermost size channel) with an exponential function of the form $10^{c_{0}+c_{1} p}$, where $p$ is the particle size range in nanometres and $c_{0}$ and $c_{1}$ are the fit parameters. To improve the fit, only size channels with a count rate larger than $3 \times 10^{-2}$ particles $\mathrm{cm}^{-3}$ are included in the fit because of the counting statistics. The exponential form of the fit is the simplest way of extending the size distribution without knowledge about the real size distribution. It is further supported by the size distributions found by Schumann et al. (2011, their Fig. 7) in Eyjafjallajökull volcanic clouds which show a continuous extension of the size distributions from particles below $1 \mu \mathrm{m}$ to larger particles. An example for this fit is shown in Fig. 3 which shows the size distribution measured on 19 May 2011 at 11:14 UTC for $n=1.50-0.01 \mathrm{i}$ with red bars and the linear fit with the blue line. This fit is then used to extend the OPC size range with additional "virtual" size channels (indicated by the magenta bars) until the number of particles is reached that the OPC has counted in its uppermost channel or the centre diameter of the virtual channel exceeds $10 \mu \mathrm{m}$. At a particle diameter of $5 \mu \mathrm{m}$ the inlet efficiency has dropped to $\sim 60 \%$ and for particles larger than $10 \mu \mathrm{m}$ in diameter the inlet efficiency is zero, i.e. they are not collected by the inlet or are lost in the sampling lines to the OPC (see Sect. 2.1). If the extrapolation would require particles larger than $10 \mu \mathrm{m}$ to explain the number of particles in the uppermost OPC channel, the slope $c_{1}$ of the extrapolated size distribution is increased iteratively until the sum 
of the particles in the virtual size channels reaches the number of particles counted in the uppermost OPC channel. In the example in Fig. 3 this was not necessary and the largest "virtual" size channel is centred at $2.21 \mu \mathrm{m}$. Its value is calculated such that the sum of all "virtual" particles equals the particles in the uppermost OPC channel. In addition to the actual slope from the linear fit, the extrapolation is repeated for the maximum slope encountered in the volcanic clouds for each refractive index (green bars) and a minimum slope of 0.0 (orange bars, see further explanation in Sect. 4.3). The particle mass is then calculated with the appropriate particle density for ammonium sulphate (background aerosol) or volcanic ash (volcanic cloud aerosol). Note that since the total particle number is fixed, the extrapolation using the smallest slope will extend to the largest particle sizes and hence give the highest particle masses. The unknown shape of the size distribution for particle diameters larger than $\sim 1.0 \mu \mathrm{m}$ is one of the major sources of uncertainty for the derived aerosol mass concentrations.

\subsection{Condensation particle counters and particle sampler}

In addition to the OPC, the CARIBIC container equipment includes three condensation particle counters (CPC, modified TSI model 7610) with lower threshold diameters (50\% counting efficiency) of $4 \mathrm{~nm}, 12 \mathrm{~nm}$ and $18 \mathrm{~nm}$, respectively, at $200 \mathrm{hPa}$ operating pressure (Hermann and Wiedensohler, 2001). The upper detection limit of all CPCs is estimated to be about $2 \mu \mathrm{m}$ in diameter.

Besides the four particle counting instruments, there is a particle sampler with 16 impactor chambers and an upstream cyclone separator covering the particle diameter range from $80 \mathrm{~nm}$ to $2 \mu \mathrm{m}$ (50\% counting efficiencies, Nguyen et al., 2006). The sampler employs sampling substrates of polyimide film $(0.2 \mu \mathrm{m}$ thickness) which are analysed post flight at the University of Lund (Sweden) for the elemental composition of the aerosol particles. Particle Elastic Scattering Analysis (PESA) is used for the elements $\mathrm{H}, \mathrm{C}, \mathrm{N}$ and $\mathrm{O}$, and Particle Induced X-ray Emission (PIXE) for the heavier elements, including $\mathrm{Si}, \mathrm{S}, \mathrm{K}, \mathrm{Ca}, \mathrm{Ti}, \mathrm{Mn}, \mathrm{Fe}$ and $\mathrm{Ni}$ (Nguyen and Martinsson, 2007).

\subsection{The new high resolution whole air sampling system}

The new whole air sampling system comprises a unit with two stainless steel bellows pumps, two units with 14 glass sampling flasks (2.71) each and a large unit with 88 stainless steel sampling cylinders (1.0 1). The latter were incorporated into the CARIBIC container in autumn 2009 and were flown for the first time during the CARIBIC volcano flights. Flasks and cylinders are filled to $\sim 4.5$ bar according to a predefined schedule with regular sampling intervals during the flight. While the actual time required for filling the sampling flasks or steel cylinders depends on the ambient pres- sure and lies in the range of $30 \mathrm{~s}-90 \mathrm{~s}$, the sampling interval is chosen to achieve a regular sampling over the entire flight. For the volcano flights, which were shorter than the regular CARIBIC flights, this meant a spacing of $8 \mathrm{~min}$ for the glass flask samples. These was the shortest possible interval including the necessary purging of the sampling containers prior to the actual sampling. The samples were analysed after each flight in the laboratory for the greenhouse gases carbon dioxide $\left(\mathrm{CO}_{2}\right)$, methane $\left(\mathrm{CH}_{4}\right)$, nitrous oxide $\left(\mathrm{N}_{2} \mathrm{O}\right)$ and sulphur hexafluoride $\left(\mathrm{SF}_{6}\right)$ with a HP 6890 gas chromatograph equipped with a flame ionisation detector for $\mathrm{CO}_{2}$ and $\mathrm{CH}_{4}$ and an electron capture detector for $\mathrm{N}_{2} \mathrm{O}$ and $\mathrm{SF}_{6}$ (see details in Schuck et al., 2009). The precision of the greenhouse gas measurements are $0.08 \%, 0.17 \%, 0.15 \%$ and $1.5 \%$ for $\mathrm{CO}_{2}, \mathrm{CH}_{4}, \mathrm{~N}_{2} \mathrm{O}$ and $\mathrm{SF}_{6}$, respectively. A suite of nonmethane hydrocarbons (NMHCs) including ethane $\left(\mathrm{C}_{2} \mathrm{H}_{6}\right)$, ethyne $\left(\mathrm{C}_{2} \mathrm{H}_{2}\right)$, propane $\left(\mathrm{C}_{3} \mathrm{H}_{8}\right)$, butanes $\left(\mathrm{C}_{4} \mathrm{H}_{10}\right)$, pentanes $\left(\mathrm{C}_{5} \mathrm{H}_{12}\right)$ and benzene $\left(\mathrm{C}_{6} \mathrm{H}_{6}\right)$ were measured using cryogenic pre-concentration and focusing of the NMHCs in combination with a second HP 6890 gas chromatograph equipped with a flame ionisation detector (see details in Baker et al., 2010). This analysis gives a precision of better than $5 \%$ and lower detection limits of 1 pptv-3 pptv.

\subsection{Other instruments}

The CARIBIC Multi-AXis Differential Optical Absorption Spectrometer (MAX-DOAS) system is connected to the three DOAS telescopes in the CARIBIC inlet system via three quartz fibre bundles. It observes the atmosphere under elevation angles of $-82^{\circ}$ (nadir), $-10^{\circ}$ and $+10^{\circ}$ relative to the horizon (for details see Dix et al., 2009; Heue et al., 2010). The DOAS system has also been upgraded in autumn 2009. The three new CTF60 spectrometers (omt - optische messtechnik, Germany) cover the wavelength range of $290 \mathrm{~nm}$ to $430 \mathrm{~nm}$ with a spectral resolution of $0.5 \mathrm{~nm}$ (Heue et al., 2010). During the CARIBIC volcano flights on 20 April and 16 May 2010, the nadir and the $-10^{\circ}$ DOAS channels gave a signal large enough for the derivation of $\mathrm{SO}_{2}$ slant column densities. On $16 \mathrm{May}, \mathrm{BrO}$ and $\mathrm{O}_{4}$ as proxy for the aerosol optical depth were retrieved in addition (see details in Heue et al., 2011). During the last volcano flight on 19 May 2010, the MAX-DOAS system unfortunately failed.

For the measurement of carbon monoxide (CO), a fast response vacuum UV resonance fluorescence instrument based on the Aero-Laser Model AL 5002 is employed. It measures $\mathrm{CO}$ via a resonance-fluorescence transition around $150 \mathrm{~nm}$. The instrument has an excellent linearity and a precision of $3.5 \mathrm{ppb}$ when the signal is integrated over 1 second. In-flight calibrations are performed every 25 min using a calibration air mixture (see details in Scharffe et al., 2012).

For ozone $\left(\mathrm{O}_{3}\right)$, two different instruments are used. The absolute $\mathrm{O}_{3}$ mixing ratio is measured with a custommade, light-weight and accurate dual-beam UV photometer with a time resolution of $4 \mathrm{~s}$. A UV-LED at $255 \mathrm{~nm}$ 
(bandwidth $\sim 6 \mathrm{~nm}$ ) is used as a light source. The total accuracy is $\sim 2 \%$ or 1 ppbv, whatever is higher. In addition, a very fast and precise solid-state chemiluminescence detector measures $\mathrm{O}_{3}$ with a measurement frequency of $10 \mathrm{~Hz}$ equivalent to a horizontal resolution of $30 \mathrm{~m}-40 \mathrm{~m}$ at normal cruising speeds. The absolute $\mathrm{O}_{3}$ measurements of the UV photometer are used to calibrate the fast chemiluminescence data (for more details see Zahn et al., 2011).

The overall system control in the CARIBIC container is achieved through the CARIBIC master computer which communicates with all instruments via an internal bus system. It also records once per second the flight position, flight altitude, airspeed, outside air pressure, air temperature and wind speed received from the aircraft via its ARINC-428 bus system.

\subsection{Meteorological information}

The Royal Netherlands Meteorological Institute (KNMI) supports the CARIBIC project with trajectory calculations (up to 8-day backward and 2-day forward) and further meteorological data (including potential vorticity) from the European Centre for Medium Range Forecasts (ECMWF) for all flights (van Velthoven, 2012). The trajectory model used is the KNMI TRAJKS model which applies the Petterssen integrating scheme using an integration step of $10 \mathrm{~min}$ (Scheele et al., 1996; Stohl et al., 2001). The meteorological input data is taken from the ECMWF with a vertical resolution of 90 levels (uppermost level at $0.01 \mathrm{hPa}$ ), 316 spherical harmonics for a horizontal resolution of less than $1^{\circ}$ and a time step of $6 \mathrm{~h}$ between consecutive meteorological input fields.

\subsection{FLEXPART ash dispersion simulation}

FLEXPART is a widely used Lagrangian dispersion model in ongoing development at the Norwegian Institute for Air Research (NILU) that obtains its meteorological input data from the European Centre for Medium-Range Weather Forecasts (ECMWF). It simulates the long-range and mesoscale transport, diffusion, dry and wet deposition, and radioactive decay of various tracers (see detailed description in Stohl et al., 2005). A special model run was setup for the Eyjafjallajökull 2010 eruption using a volcanic ash tracer subject to dry deposition, wet deposition and gravitational settling but ignoring ash aggregation processes. This model run uses the ash source information and initial size distribution determined via inverse modelling by Stohl et al. (2011). The inverse modelling merged a priori information on the ash emission strength, sensitivity calculations with FLEXPART and satellite retrievals of total atmospheric columns of volcanic ash to obtain optimised time- and height-resolved volcanic ash emissions. Emissions and thus modelled ash dispersion patterns are well constrained by the satellite observations for strong ash clouds. The satellite measurement constraint is less good for ash clouds with lower ash loadings or for defin- ing the volcanic cloud edges because of the limited sensitivity of the satellite retrievals. Thus, the model performance for the relatively weak clouds sampled by the CARIBIC aircraft may be not as good as for stronger ash clouds.

In the model run used for the comparison to the CARIBIC measurements 24 million volcanic ash particles were released in 22 size classes between $250 \mathrm{~nm}$ and $250 \mu \mathrm{m}$ to obtain vertically resolved ash concentrations (Stohl et al., 2011). The gravitational settling of the particles was calculated using an ash particle density of $3.0 \mathrm{gcm}^{-3}$. For a consistent comparison to the OPC mass concentrations, all FLEXPART ash concentrations shown here have been scaled to an ash particle density of $2.65 \mathrm{gcm}^{-3}$ as used in the OPC analysis, i.e. the particle mass was decreased by $12 \%$. The FLEXPART model output has a spatial resolution of $0.25 \times 0.25^{\circ}$. The vertical resolution is $250 \mathrm{~m}$ from the ground up to $7 \mathrm{~km}$ altitude, $500 \mathrm{~m}$ up to $10 \mathrm{~km}$ altitude, $1000 \mathrm{~m}$ up to $13 \mathrm{~km}$ plus an additional stratospheric layer at $20 \mathrm{~km}$. The ECMWF meteorological input data is available every three hours at a spatial resolution of $0.18 \times 0.18^{\circ}$ and 91 model levels (further details on the model simulations are available in Stohl et al., 2011). For comparison of FLEXPART predictions and CARIBIC aerosol measurements, vertical distributions of the simulated volcanic ash concentrations were extracted along the CARIBIC flight tracks.

\section{CARIBIC volcano flights}

The explosive phase of the 2010 eruption of the Eyjafjallajökull volcano began on 14 April 2010 and lead to the subsequent partial closure of European airspace. As insufficient information was available, Lufthansa offered the CARIBIC consortium the possibility of conducting a volcano measurement flight on 20 April (takeoff 13:47 UTC, landing 17:33 UTC) from Frankfurt airport (Germany), the home base of the Lufthansa CARIBIC aircraft. Heading northeastward from Frankfurt the flight track crossed North-Eastern Germany and continued over the Baltic Sea and the island of Gotland before turning northwest and passing Stockholm. Crossing Southern Sweden and Denmark the CARIBIC aircraft returned via Northern Germany to Frankfurt (left panel of Fig. 1). Between Frankfurt and Gotland island the aircraft descended and ascended repeatedly thus measuring ten vertical profiles between $3700 \mathrm{~m}$ and $8000 \mathrm{~m}$ with the aim to increase the chance of intercepting the ash cloud (see flight profile in the upper panel of Fig. 4). Another descent down to $6000 \mathrm{~m}$ followed around 16:45 UTC over the German Bight. Throughout this paper, all flight altitudes mentioned are pressure altitudes with respect to the International Standard Atmosphere (ISA, e.g. Airbus Customer Services, 2002) as reported by the aircraft via the ARINC-428 bus system. 

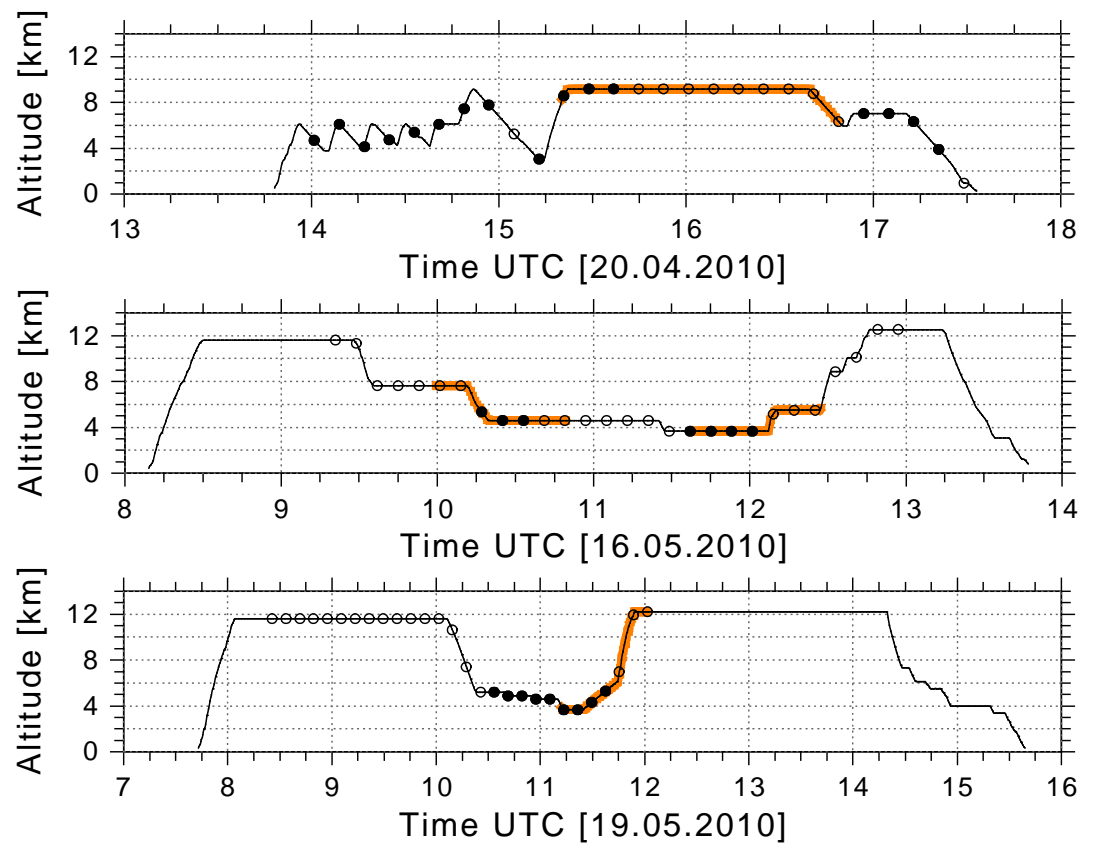

Fig. 4. Altitude profiles of the CARIBIC flights on 20 April 2010 (upper panel), 16 May 2010 (middle panel) and 19 May 2010 (lower panel). All altitudes are pressure altitude according to the International Standard Atmosphere (ISA). The whole air samples and the aerosol impactor samples are indicated in the same way as in Fig. 1.

As the volcanic eruption continued and the situation regarding air space closures remained unclear, a second CARIBIC flight from Frankfurt took place on 16 May 2010 (takeoff 08:08 UTC, landing 13:49 UTC). For this day, several volcanic ash dispersion models (see below) had predicted ash clouds over Northern Ireland and Scotland. Therefore the CARIBIC aircraft flew two south-north transects over Ireland and over the Irish Sea (middle panel of Fig. 1). Flying further north was not possible as the airspace was being closed just when the aircraft arrived there. The transfer flights to this region were carried out at cruise altitude around $12 \mathrm{~km}$. During the south-north transects, the altitude was stepwise reduced from $7600 \mathrm{~m}$ to $3700 \mathrm{~m}$ (middle panel of Fig. 4).

The right panel of Fig. 1 shows the flight route of the third and final CARIBIC volcano flight which left Frankfurt on 19 May 2010 (takeoff 07:43 UTC, landing 15:38 UTC) and headed north over the Norwegian Sea to $\left(75^{\circ} \mathrm{N}, 10^{\circ} \mathrm{E}\right)$ where the dispersion models had forecast volcanic ash clouds with areas exceeding $4 \mathrm{mgm}^{-3}$ of ash which at that time was the limit for no-fly zones (European Commission, 2010). The transfer flights were again carried out at a cruise altitude of around $12 \mathrm{~km}$ to save time and fuel. Once at destination, the altitude was stepwise reduced from $5200 \mathrm{~m}$ to $3700 \mathrm{~m}$ while flying east to $15^{\circ} \mathrm{E}$ and from there turning south again. When leaving the area of forecast ash clouds, the aircraft climbed again to cruise altitude for the return flight (lower panel of Fig. 4). The stepwise descent at the end of this flight was due to a required holding pattern before landing in Frankfurt.

During flight planning for the three CARIBIC volcano flights, ash dispersion forecasts from several sources were used. The Volcanic Ash Advisory Centre (VAAC) London issued official Volcanic Ash Advisories for three altitude regions (surface to flight level (FL) 200 (20 000 ft), FL200-350 and FL350-550) and three steps for the maximum ash concentration of $200 \mathrm{\mu gm}^{-3}, 2 \mathrm{mgm}^{-3}$ and $4 \mathrm{mgm}^{-3}$, the latter defined as the absolute no-fly zone at that time by the civil aviation authorities (European Commission, 2010). Additional ash dispersion predictions from the UK MetOffice (which also issues the VAAC forecast) with finer concentration steps were obtained from the German Weather Service (DWD). Also ash dispersion forecasts from the EURAD model (University of Cologne) and the SILAM modelling framework (Finnish Meteorological Institute) were used. The Norwegian Institute for Air Research (NILU) offers a web interface for its FLEXPART dispersion model which produces plot with a vertical resolution of one kilometre. These plots were used to determine the best flight altitude pattern for intercepting the ash clouds. In addition to dispersion models, freely available satellite data for $\mathrm{SO}_{2}$ from the GOME2 instrument (http://sacs.aeronomie.be/nrt/ index.php) and for atmospheric aerosols from the space lidar onboard the CALIPSO satellite (http://www-calipso.larc. nasa.gov/products/) were also taken into consideration to determine the most promising flight patterns. 
The flight tracks in Fig. 1 and the flight altitude profiles in Fig. 4 also include the locations and altitudes of the whole air glass flask samples. Open circles mark samples that were not influenced by the volcano and hence constitute background conditions. Solid circles show samples for which the backward trajectories calculated at KNMI showed that the air had passed over Iceland at altitudes below $9 \mathrm{~km}$, which was the maximum altitude the eruption reached during the relevant days according to Schumann et al. (2011, their Fig. 2). The parts of the flight tracks and flight profiles highlighted in orange mark the collection intervals of those aerosol particle samples for which the elemental composition clearly indicates a volcanic origin (see next section).

The transit times of the volcanic clouds, i.e. the age of the released volcanic ash, were estimated from the KNMI backward trajectory analysis. For each whole air sample 8-day backward trajectories were calculated starting at the sampling location. The mean transport time from the Eyjafjallajökull volcano to the CARIBIC sampling location was $15 \mathrm{~h}-29 \mathrm{~h}$ for the flight on 20 April, $34 \mathrm{~h}-53 \mathrm{~h}$ for 16 May and $19 \mathrm{~h}-24 \mathrm{~h}$ for the flight on 19 May 2010. The uncertainty of backward trajectories was assessed through a trajectory ensemble calculated by arbitrarily shifting starting point coordinates in latitude and longitude by $\pm 0.4^{\circ}$ and in pressure by $\pm 3 \%$. If all of these 15 back trajectories stay close together, the trajectory is well defined. In contrast, if the 15 back trajectories separate after a short time the origin of the sampled air has a large uncertainty which makes it difficult to determine whether it had been in contact with the Eyjafjallajökull eruption or not. For this study, an air sample is considered to contain volcanic ash and gases if at least seven of the 15 back trajectories pass within $200 \mathrm{~km}$ from the volcano at an altitude of $9 \mathrm{~km}$ or less. The radius of $200 \mathrm{~km}$ is used to account for the horizontal uncertainty of the trajectories caused by imperfections in both the TRAJKS trajectory model and the ECMWF wind fields. The results from the trajectory analysis confirm the results obtained from the CARIBIC measurements in separating air masses that are influenced by the Eyjafjallajökull volcano from those that are not even though the calculations did not take into account sedimentation of volcanic ash, which depends on particle mass and constitutes an additional uncertainty.

\section{Results}

The following sections present the results from the three CARIBIC volcano flights in April and May 2010. The aerosol impactor samples indicated volcanic ash particles in the probed air masses through marked changes in the elemental composition for all three measurement flights as discussed below. However, for the first flight the signal was less clear than for the subsequent flights. Therefore the focus of this paper will be on the two subsequent flights in May 2010.
Nevertheless, some useful results could also be derived from the flight on 20 April and are presented first.

\subsection{April 2010: Baltic Sea}

During this first CARIBIC volcano flight, the OPC found enhancements in particle mass concentrations (not shown) that coincided with air masses that the trajectory analysis traced back to the Eyjafjallajökull volcano (see filled dots in left panel of Fig. 1). Enhancements were found over NorthEastern Germany at an altitude of around $4 \mathrm{~km}$, close to Gotland island at $3.5 \mathrm{~km}$ altitude and over North-Western Germany around $7 \mathrm{~km}$. The ash particle mass concentrations determined as described in Sect. 2.2 in those air masses were in the range of $2.8 \mu \mathrm{gm}^{-3}-115 \mathrm{\mu gm}^{-3}$ (10\%-90\% percentiles) with a median of $41{\mu \mathrm{gm}^{-3}}^{-3}$ for the minimum slope used in the extrapolation. Using the maximum slope, the calculated ash mass concentrations were in the range of $1.8{\mu \mathrm{gm}^{-3}-}^{-}$ $17 \mathrm{gm}^{-3}$ with a median of $6.5 \mu \mathrm{gm}^{-3}$. All numbers are calculated over all values received using the three volcanic ash refractive indices. The highest value observed in the $180 \mathrm{~s}$ binning time was $277 \mu \mathrm{gm}^{-3}$ for minimum slope $\left(271 \mu \mathrm{gm}^{-3}\right.$ for maximum slope) at $14: 27$ UTC and $4.5 \mathrm{~km}$ altitude over North-Eastern Germany. For the non-volcanic aerosol measurements, the range was $0.8 \mu \mathrm{gm}^{-3}-22 \mu \mathrm{gm}^{-3}$ with a median of $1.4 \mu \mathrm{gm}^{-3}$ for the linear extrapolation. All particle number and mass concentrations in this study are given for ambient pressure and temperature conditions.

For technical reasons, the aerosol sampler collected only one sample during the first volcano flight on 20 April 2010 (integration time 15:20-16:48 UTC; orange highlighted part of flight track in left panel of Fig. 1). This sample had an exceptionally high iron content of $2.4 \mathrm{wt} . \%$ of the total particle mass (see elemental composition of the samples listed in Table 2). In fact, this is the highest iron fraction ever measured in the CARIBIC project. The silicon content was $2.5 \mathrm{wt} . \%$ which is much larger than in the background aerosol samples collected during the other two flights most of which contained less than $0.5 \mathrm{wt} \%$ of silicon. The low mass ratios of silicon $(\mathrm{Si})$, potassium $(\mathrm{K})$ and calcium $(\mathrm{Ca})$ to iron (Fe) of 1.0, 0.19 and 0.20, respectively, confirm the high iron content of the sampled aerosol particles during this flight.

The whole air samples during the 20 April 2010 flight did not show any peculiarities that would point to a volcanic influence in the sampled air. The MAX-DOAS system measured a slight enhancement of $\mathrm{SO}_{2}$ close to Gotland island around 15:15 UTC. Unfortunately, the signal strength of the DOAS instrument was very low during this flight and the enhancement did not rise significantly over the signal noise level. The DOAS BrO signal did not show any increase. Also the in situ trace gas analysers did not show any peculiarities. 
Table 2. Relative mass contents and mass ratios of those elements that were enhanced in the volcanic ash samples collected by the aerosol impactor sampler during the three CARIBIC volcano flights. The samples containing volcanic ash are marked in bold. Sample 8 on 20 April and sample 5 on 19 May probably represent a mixture of air with and without volcanic influence and are therefore shown in bold italics. The values derived from Sigmundsson et al. (2010) are means for their samples SRG 2b and SRG 5a collected on 15 April and 27 April 2010 in the vicinity of the Eyjafjallajökull.

\begin{tabular}{|c|c|c|c|c|c|c|c|c|c|c|}
\hline volcanic & c? sample & $\mathbf{S i}$ & $\mathbf{S}$ & $\mathbf{K}$ & $\mathbf{C a}$ & $\mathrm{Fe}$ & $\mathrm{Si} / \mathbf{F e}$ & $\mathrm{S} / \mathrm{Fe}$ & $\mathrm{K} / \mathrm{Fe}$ & $\mathrm{Ca} / \mathrm{Fe}$ \\
\hline mixed 2 & 20 April no. 8 & $2.5 \%$ & $19 \%$ & $0.45 \%$ & $0.48 \%$ & $2.4 \%$ & 1.0 & 7.9 & 0.19 & 0.20 \\
\hline No & 16 May no. 2 & $0.18 \%$ & $21 \%$ & $0.20 \%$ & $0.074 \%$ & $0.13 \%$ & 1.3 & 157 & 1.5 & 0.56 \\
\hline No & 16 May no. 3 & $0.44 \%$ & $20 \%$ & $0.37 \%$ & $0.13 \%$ & $0.40 \%$ & 1.1 & 49 & 0.92 & 0.32 \\
\hline Yes & 16 May no. 4 & $10.0 \%$ & $10 \%$ & $\mathbf{0 . 8 1} \%$ & $1.1 \%$ & $1.9 \%$ & 5.2 & 5.5 & 0.42 & 0.59 \\
\hline No & 16 May no. 5 & $1.2 \%$ & $12 \%$ & $0.39 \%$ & $0.10 \%$ & $0.29 \%$ & 4.0 & 41 & 1.3 & 0.33 \\
\hline Yes & 16 May no. 6 & $9.1 \%$ & $11 \%$ & $0.91 \%$ & $1.2 \%$ & $2.1 \%$ & 4.4 & 5.5 & 0.44 & 0.56 \\
\hline No & 16 May no. 7 & $0.18 \%$ & $20 \%$ & $0.52 \%$ & $0.10 \%$ & $0.17 \%$ & 1.1 & 119 & 3.1 & 0.61 \\
\hline No & 19 May no. 2 & $0.54 \%$ & $18 \%$ & $0.60 \%$ & $0.15 \%$ & $0.073 \%$ & 7.4 & 243 & 8.3 & 2.0 \\
\hline No & 19 May no. 3 & $0.38 \%$ & $18 \%$ & $0.55 \%$ & $0.11 \%$ & $0.12 \%$ & 3.3 & 153 & 4.7 & 0.98 \\
\hline No & 19 May no. 4 & $0.44 \%$ & $19 \%$ & $1.1 \%$ & $0.13 \%$ & $0.31 \%$ & 1.4 & 59 & 3.4 & 0.41 \\
\hline mixed 1 & 19 May no. 5 & $4.0 \%$ & $16 \%$ & $0.98 \%$ & $0.14 \%$ & $0.70 \%$ & 5.7 & 22 & 1.4 & 0.20 \\
\hline Yes 1 & 19 May no. 6 & $9.7 \%$ & $12 \%$ & $1.2 \%$ & $\mathbf{0 . 8 7} \%$ & $2.3 \%$ & 4.3 & 5.1 & 0.53 & 0.38 \\
\hline No & 9 May no. 7 & $0.17 \%$ & $19 \%$ & $0.55 \%$ & $0.093 \%$ & $0.14 \%$ & 1.3 & 142 & 4.0 & 0.68 \\
\hline \multicolumn{2}{|c|}{ Sigmundsson et al. (2010) } & $27 \%$ & - & $1.4 \%$ & $4.1 \%$ & $7.6 \%$ & 3.5 & - & 0.19 & 0.54 \\
\hline
\end{tabular}

\subsection{May 2010: Ireland and Irish Sea}

The CPC particle number concentrations at ambient pressure and temperature during the second CARIBIC volcano flight on 16 May are shown in the upper panel of Fig. 5 where volcanic cloud encounters are marked by arrows. They show an increase in the number of particles with diameters larger than $12 \mathrm{~nm}$ (red line) and larger than $18 \mathrm{~nm}$ (black line) from $\sim 1.5 \times 10^{3}$ particlescm $^{-3}$ in the background air up to $1.8 \times 10^{4}$ particlescm $^{-3}$ during 10:17-10:40 UTC when the aircraft turned around north of Ireland and descended into the volcanic cloud (see middle panels of Figs. 1 and 4). Unfortunately, the brand-new OPC, employed in airborne measurements for the first time during the CARIBIC volcano flights, did not work during this second flight. Therefore no continuous particle mass concentrations are available for this flight.

The aerosol impactor sampler was set to an integration time of 50 min during this flight and elemental analyses gave clear indications of volcanic ash for samples no. 4 (sampling interval 09:59-10:49 UTC) and no. 6 (sampling interval 11:38-12:27 UTC, see orange highlighted parts of the flight track in middle panel of Fig. 1 and Table 2). Both samples showed high silicon and iron fractions of $10.0 \mathrm{wt} . \% \mathrm{Si}$ and $1.3 \mathrm{wt} . \% \mathrm{Fe}$ for sample no. 4 and $9.1 \mathrm{wt} . \% \mathrm{Si}$ and $2.1 \mathrm{wt} . \% \mathrm{Fe}$ for sample no. 6, which is much higher than the fractions present in the non-volcanic samples ( $\mathrm{Si}$ up to $0.5 \mathrm{wt} . \%, \mathrm{Fe}$ up to $0.4 \mathrm{wt} . \%$ ). Also the fractions of calcium (1.2 wt.\% vs. $0.15 \mathrm{wt} . \%)$ and titanium ( 0.26 wt. $\%$ vs. 0.03 wt. $\%$ ) are clearly enhanced in relation to the non-volcanic samples. For the two volcanic samples, the ratios of $\mathrm{Si} / \mathrm{Fe}, \mathrm{K} / \mathrm{Fe}$ and $\mathrm{Ca} / \mathrm{Fe}$ were $5.2 \& 4.4,0.42 \& 0.44$ and $0.59 \& 0.56$, respectively.

The MAX-DOAS system measured strong enhancements of $\mathrm{SO}_{2}$ (up to $49 \mathrm{ppb}$ ) and $\mathrm{BrO}$ (up to $6 \mathrm{ppt}$ ) during those parts of the flight on 16 May where the air was traced back to the volcano (see filled dots in Fig. 1). While the CARIBIC aircraft flew north over the Irish Sea it encountered once again air coming from the volcano (11:55-12:10 UTC) with a much smaller increase in $\mathrm{SO}_{2}$ and no increase in $\mathrm{BrO}$. Also the CPCs detected again increased particle number concentrations, e.g. of the particles with diameters larger than $12 \mathrm{~nm}$ with $7 \times 10^{3}$ particlescm $\mathrm{C}^{-3}$. A detailed discussion of the MAX-DOAS measurements during this flight has been published in a companion article in this special issue by Heue et al. (2011).

The CO measurements during this flight are shown in the lower panel in Fig. 5 (black line). The background CO concentration outside the volcanic air is $120 \mathrm{ppbv}$, a usual background value for this region in May. When the aircraft descended into the volcanic cloud around 10:17 UTC, the $\mathrm{CO}$ concentration rose to $200 \mathrm{ppbv}$ but shortly after returned to the background value although the aircraft was still inside the volcanic cloud according to the CPC measurements and the backward trajectories. A smaller increase to $155 \mathrm{ppbv}$ was detected at 12:00 UTC when the aircraft measured the second volcanic cloud over the Irish Sea. The measured ozone concentrations (green line in lower panel of Fig. 5) did not show a significant change of the ozone inside the volcanic clouds. 


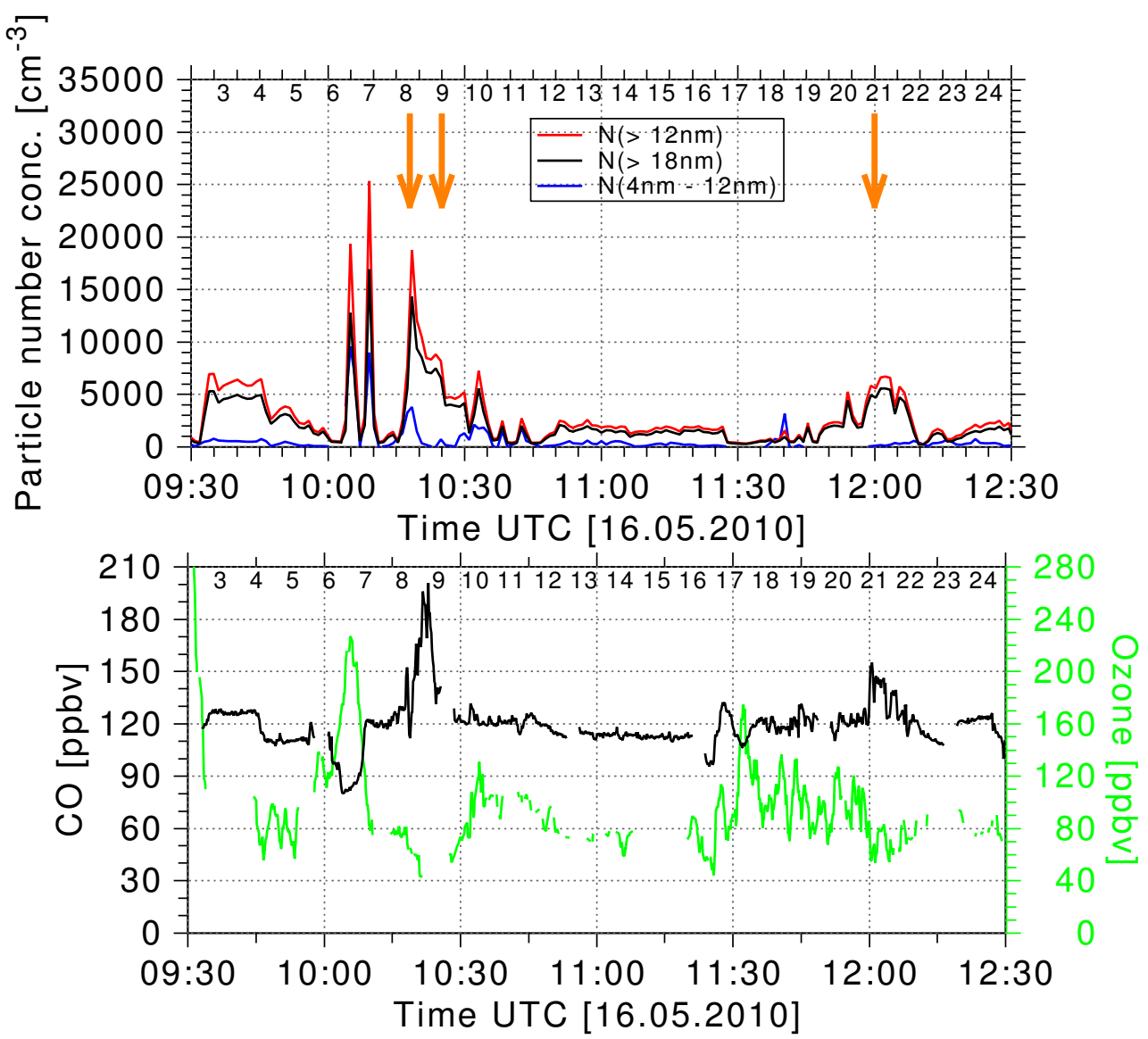

Fig. 5. Measurements from the CARIBIC volcano flight on 16 May 2010 at the time of volcanic cloud interception (see arrows). The numbers close to the upper margin mark the whole air samples. Upper panel: particle number concentrations from the CPCs in different size ranges for nucleation mode particles $(4 \mathrm{~nm}-12 \mathrm{~nm}$ diameter, blue), particles between $12 \mathrm{~nm}$ and $2 \mu \mathrm{m}$ diameter (red) and particles between $18 \mathrm{~nm}$ and $2 \mu \mathrm{m}$ diameter (black). Lower panel: carbon monoxide ( $\mathrm{CO}$, in black) and ozone $\left(\mathrm{O}_{3}\right.$, in green). Gaps in the time series are caused by calibrations $(\mathrm{CO})$ or missing data $\left(\mathrm{O}_{3}\right)$.

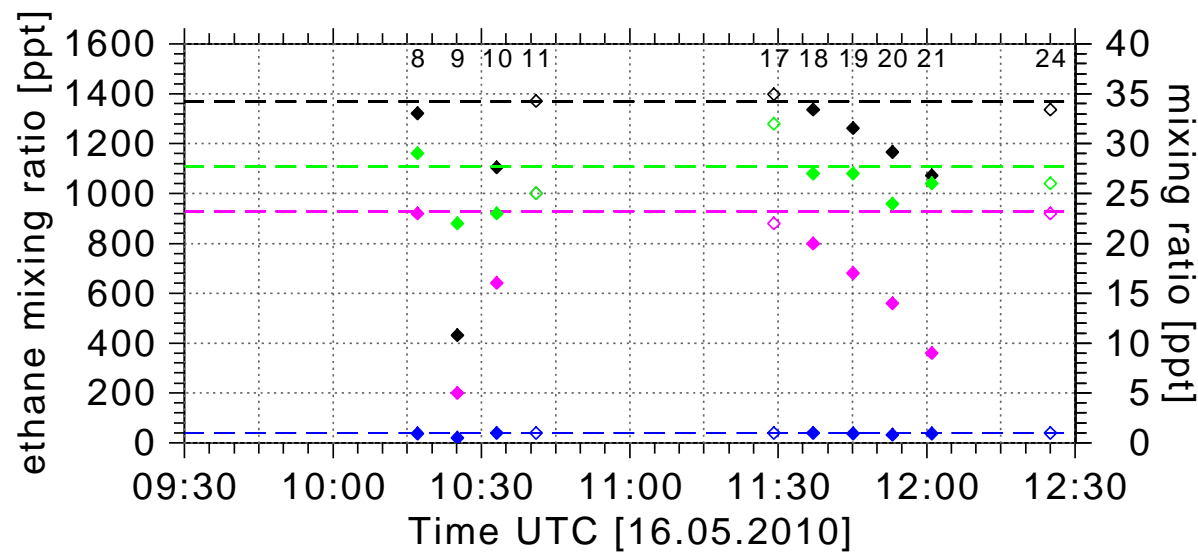

Fig. 6. Selected non-methane hydrocarbons (NMHCs) and perchloroethylene (PCE) measurements in whole air samples collected on 16 May 2010. Shown are ethane (black, left scale), n-butane (magenta, right scale), benzene (green, right scale) and PCE (blue, right scale). The whole air sample numbers are printed close to the upper margin. Open symbols denote samples outside the volcanic clouds, filled samples are from within the volcanic clouds. The dashed lines indicate the mean background concentrations outside the volcanic clouds. 


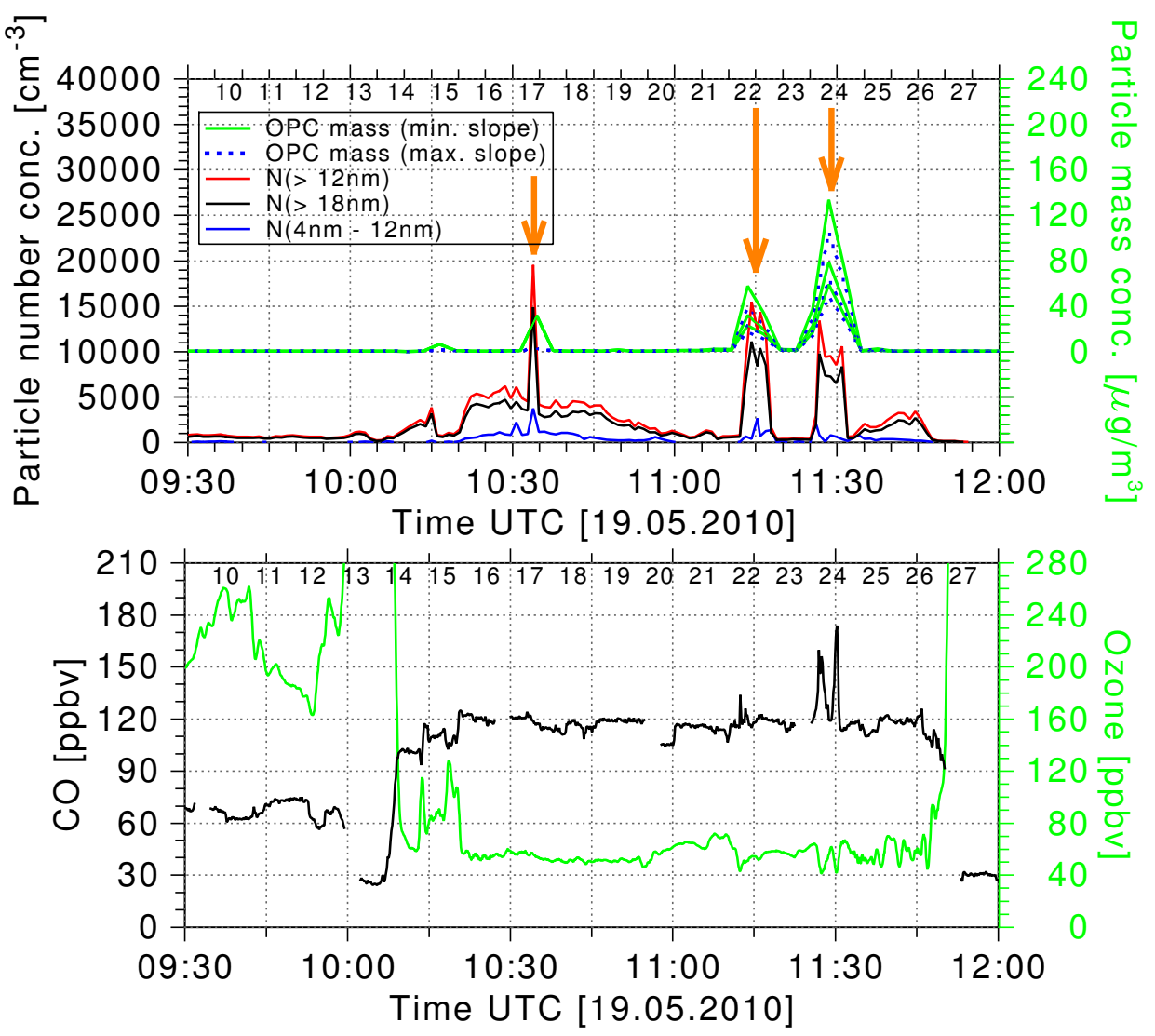

Fig. 7. Measurements from the CARIBIC volcano flight on 19 May 2010 during the volcanic cloud encounter (see arrows). Same representation as in Fig. 5. Additionally, OPC particle mass concentrations for particles larger than $138 \mathrm{~nm}$ are shown in the upper panel (right scale). The solid green lines show the mass concentration assuming the smallest slope while the dotted blue lines are calculated assuming the largest slope in the size distribution extrapolation. The three lines are calculated assuming different refractive indices for the volcanic ash particles (see text).

The whole air samples, analysed for a suite of nonmethane hydrocarbons, showed a clear decrease of ethane, ethyne, propane, butanes and pentanes in those air samples which were traced back to the Eyjafjallajökull (samples no. 8-10 and no. 18-21, see filled symbols and numbers close to upper margin in Fig. 6) compared to background air samples (see open symbols and dashed lines indicating the mean background concentrations). Also the perchloroethylene (PCE) mixing ratios (shown in blue) are slightly lower inside the volcanic cloud than outside. Interestingly, benzene (shown in green) did not show such a decrease in the volcanic air samples. This depletion pattern was attributed to chlorine radical chemistry occurring inside the volcanic clouds (see detailed analysis in Baker et al., 2011). Using transport times from the backward trajectories, the estimated mean chlorine radical concentration during the transport to the British Isles was $1.3-6.4 \times 10^{4} \mathrm{Clcm}^{-3}$ with a mean of $3.0 \times 10^{4} \mathrm{Clcm}^{-3}$.

\subsection{May 2010: Norwegian Sea}

During the final CARIBIC volcano flight on 19 May 2010, the aircraft sampled between 10:15 UTC and 11:45 UTC in a region with predicted volcanic ash in the middle troposphere over the Norwegian Sea. Like during the previous flights, the aircraft approached and left this region flying at cruise altitude (see lower panel of Fig. 4). The OPC worked well during this flight and the inferred particle mass concentrations are shown in the upper panel of Fig. 7 (solid green and dotted blue lines, right scale) where volcanic cloud encounters are marked by arrows. The solid green lines are for the minimum slope while the dotted blue lines are for the maximum slope used in the extrapolation for particles larger than the upper detection limit of the OPC (see below and description of OPC analysis in Sect. 2.2). The OPC derived particle mass and number size distribution are used to distinguish background air from the volcanic clouds. The aerosol background is determined from the measurements during 10:37-10:59 UTC. During the volcanic ash encounter at 11:01-11:38 UTC, the 
maximum fitted slopes are $+1.20 /+1.28 /+1.34$ for the three volcanic ash refractive indices. Based on the individual $180 \mathrm{~s}$ particle number size distributions, a constant extension of the size distribution (slope $=0.0$ ) is assumed as the minimum slope during the volcanic cloud encounter. The size distribution measured at 11:14 UTC is shown as an example in Fig. 3 which also shows the extrapolation to "virtual" size channels for the slope from the linear fit (magenta bars) and for minimum and maximum slope (orange and green bars).

A smaller slope in the extrapolation extends the size distribution to larger particle diameters before the number of particles counted is reached. Therefore the derived particle mass is higher for the smaller slope (green solid lines in upper panel of Fig. 7) than for the larger slope (blue dotted lines) of the extrapolation. The highest particle masses are derived when using the smallest refractive index of $n=1.50$ 0.01i. There are two peaks in the OPC mass concentrations:

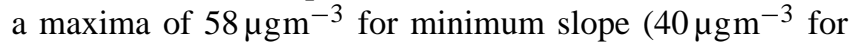
maximum slope) at 11:14 UTC and $133 \mu \mathrm{gm}^{-3}\left(107 \mu \mathrm{gm}^{-3}\right.$ for maximum slope) at 11:29 UTC (again all values given are for ambient pressure and temperature). A third much smaller increase was measured at 10:34 UTC with a mass concentration of $6.4 \mathrm{\mu gm}^{-3}\left(4.5 \mathrm{\mu gm}^{-3}\right.$ for maximum slope) coinciding with a narrow peak in the CPC particle number concentrations. For a refractive index of $n=1.60$ $0.0001 \mathrm{i}$, the corresponding values are $23 \mu \mathrm{gm}^{-3}, 59 \mu \mathrm{gm}^{-3}$ and $2.3 \mu \mathrm{gm}^{-3}$ using the minimum slope in the extrapolation. The mean aerosol background is determined from the measurements during 10:37-10:59 UTC and found to be $0.3 \mu \mathrm{gm}^{-3}-1.2 \mu \mathrm{gm}^{-3}(10 \%-90 \%$ percentiles $)$ with a median of $0.5 \mu \mathrm{gm}^{-3}$ for the linear extrapolation.

The CPCs detected maxima in the number concentration of particles with diameters larger than $12 \mathrm{~nm}\left(\mathrm{~N}_{12}\right)$ and $18 \mathrm{~nm}$ of up to $1.6 \times 10^{4}$ particlescm ${ }^{-3}$ (Fig. 7, red and black solid lines, left scale). For nucleation mode particles (blue line) there are maxima around 10:34 UTC and 11:15 UTC coinciding with the first two peaks in the OPC particle mass and the other CPC particle ranges, while for the last particle mass maximum the peak for the nucleation mode particles occurs at the beginning when the concentrations in the other two CPC particle size ranges are just starting to increase.

The measured particle mass size distributions averaged over the background and the volcanic ash periods of the flight on 19 May 2010 are shown in the upper panel of Fig. 8. The blue bars represent the mean background size distribution while the red and gray bars show the mean size distribution of the volcanic ash for the two extreme ash refractive indices. Error bars indicate the 1- $\sigma$ variability during the two averaging periods. Inside the volcanic ash cloud, all size channels have higher particle masses than in the background air. But the most pronounced difference is found for particle diameters larger than $450 \mathrm{~nm}$ where the mass per size channel increases with particle size for the volcanic ash while it stays more or less constant for the background aerosol. The error bars for the uppermost size interval are calculated using the
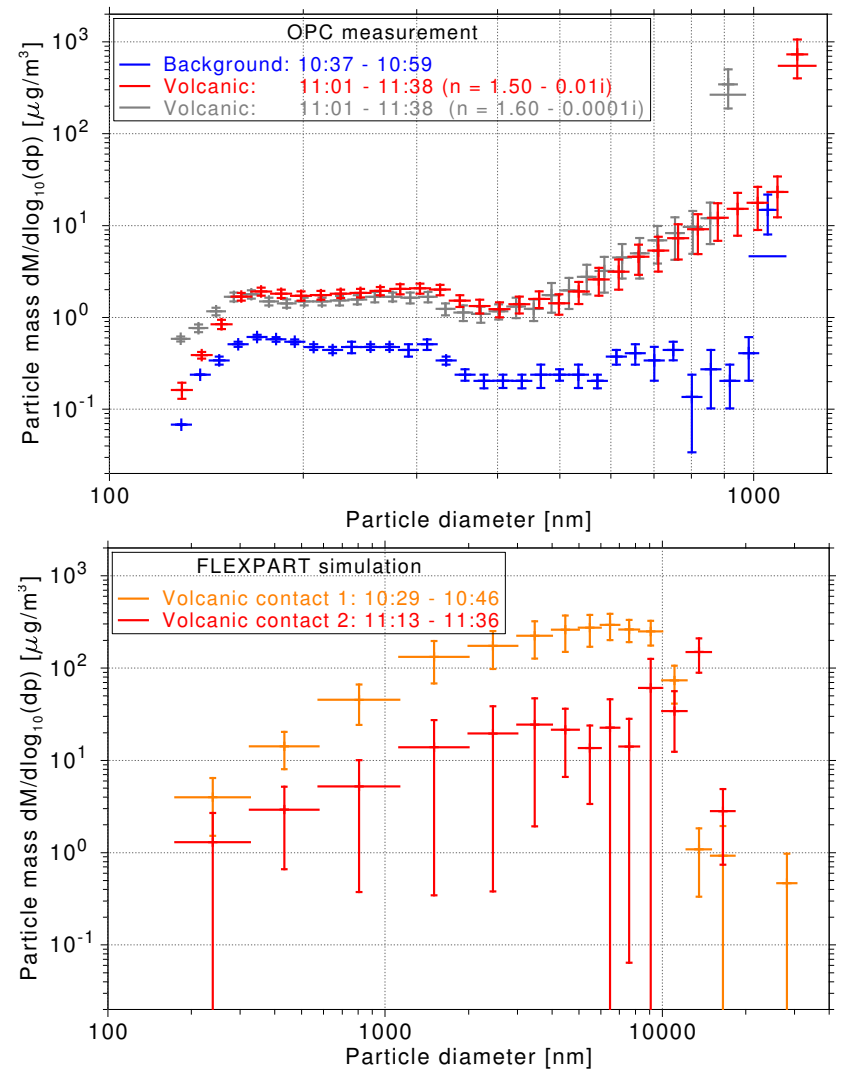

Fig. 8. Measured and modelled particle mass size distributions for the CARIBIC flight on 19 May 2010. Upper panel: measured OPC size distributions. Shown are averaged distributions for the background aerosols (blue) and for the volcanic ash cloud (red \& gray). Error bars indicate the $1-\sigma$ variability for the two periods. The solid bars show the mass calculated with the smallest slope for the size distribution extrapolation. The long bars at the uppermost size channel show the derived mass if the largest slope is used in the extrapolation. Lower panel: ash particle size distributions from the FLEXPART simulations averaged over the first predicted ash cloud encounter (orange, not observed with the OPC) and the second ash encounter (red, confirmed by the OPC measurements). Note the different $\mathrm{x}$-axes.

smallest slope for the extrapolation of the size distribution. The long bars at the uppermost size channel are calculated using the maximum slope as described above.

During the third CARIBIC volcano flight, only one aerosol sample showed volcanic particles (sample no. 6, pre-defined sampling interval 11:12-12:01 UTC, see Table 2). Mass fractions of $2.3 \mathrm{wt} . \%$ iron, $9.7 \mathrm{wt} . \%$ silicon, $0.87 \mathrm{wt} . \%$ calcium and $0.27 \mathrm{wt} . \%$ titanium were measured. As the aircraft left the ash cloud around 11:40 UTC, half of the sampling interval was in background air. Sample no. 5 collected earlier from 10:22-11:12 UTC is a mixture of background aerosols and volcanic ash which contained less silicon and less iron (e.g. $\mathrm{K} / \mathrm{Fe}$ ratio 1.4 vs. 0.53 for the later sample no. 6 ). 


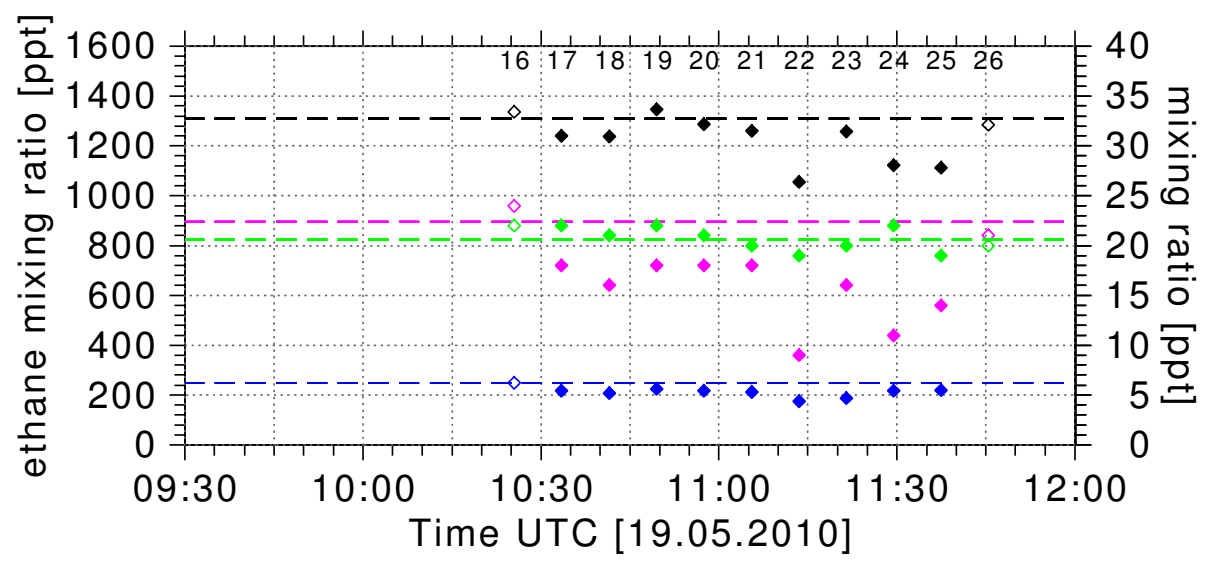

Fig. 9. Selected non-methane hydrocarbons (NMHCs) and perchloroethylene (PCE) measurements in whole air samples collected on 19 May 2010. Same representation as in Fig. 6.

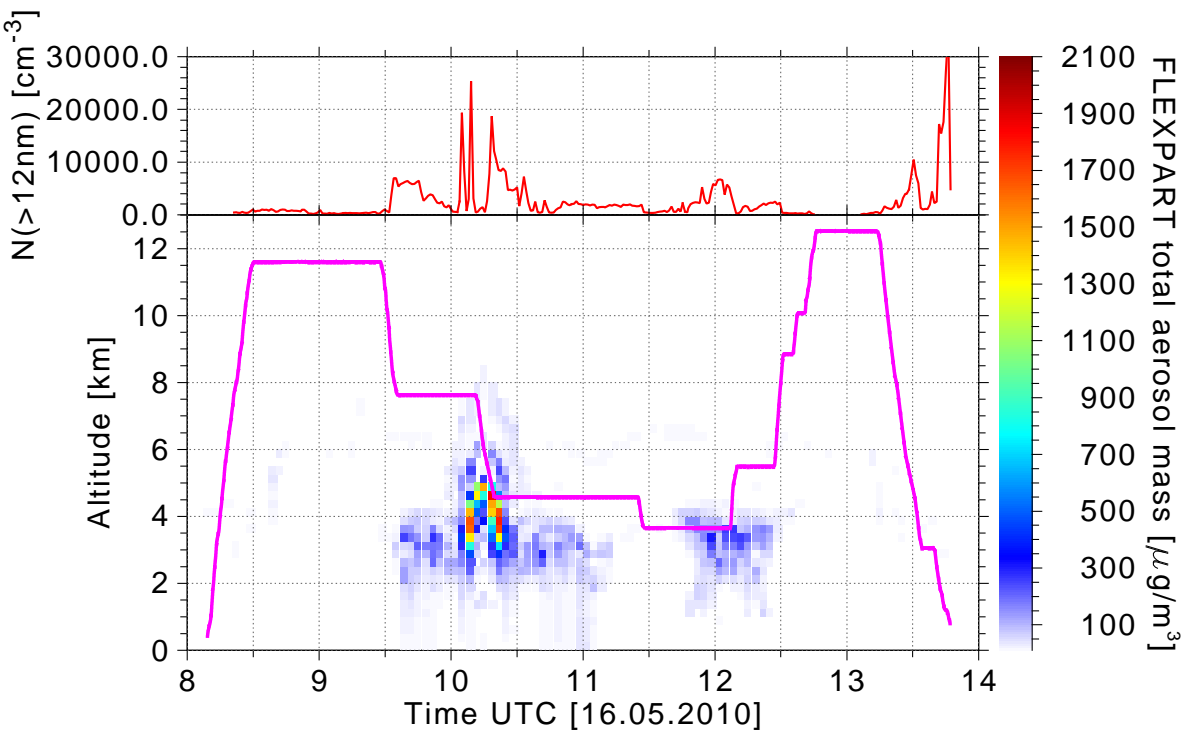

Fig. 10. Particle measurement and model comparison for flight on 16 May 2010. Upper panel: CPC particle number concentration for particles between $12 \mathrm{~nm}$ and $2 \mu \mathrm{m}$. Lower panel: simulated vertical distribution of the ash along the flight track from the FLEXPART model. The magenta line gives the CARIBIC pressure altitude as reported by the aircraft. The modelled total ash particle mass is colour-coded. Ash particle mass concentrations of less than $10 \mu \mathrm{gm}^{-3}$ are not shown.

The continuous measurements of $\mathrm{CO}$ (black line, left scale) and $\mathrm{O}_{3}$ (green line, right scale) are shown in the lower panel of Fig. 7. During the flight section of interest between 10:15 UTC and 11:45 UTC, the CO concentration stays fairly constant at around $120 \mathrm{ppbv}$ while the $\mathrm{O}_{3}$ concentration is $\sim 60 \mathrm{ppbv}$ (a typical value for the mid-troposphere in May at $75^{\circ} \mathrm{N}$, Fortuin and Kelder, 1998). After 11:45 UTC the aircraft climbed to cruise altitude and entered the lower stratosphere (according to ECMWF potential vorticity). This explains the high $\mathrm{O}_{3}$ and low $\mathrm{CO}$ values at this time. During the first aerosol peak around 11:13 UT, there is only a very short and small increase in $\mathrm{CO}$ and a small decrease in $\mathrm{O}_{3}$. However during the second aerosol peak around 11:28 UT, there are clearly two strong $\mathrm{CO}$ peaks of up to $179 \mathrm{ppbv}$ (an increase of $60 \mathrm{ppbv}$ or $50 \%$ over the background).

The non-methane hydrocarbons for the 19 May 2010 flight showed similar systematic decreases as during the second volcano flight on 16 May and the volcanic signature was even more clear. The chlorine radical concentration estimated from whole air samples no. 17-25 (see filled symbols and numbers close to upper margin in Fig. 9) is $2.0-5.7 \times 10^{4} \mathrm{Clcm}^{-3}$ (see detailed discussion in Baker et al., 2011). The MAX-DOAS system was not working during this flight so there is no information about the $\mathrm{SO}_{2}$ or $\mathrm{BrO}$ concentration available. 


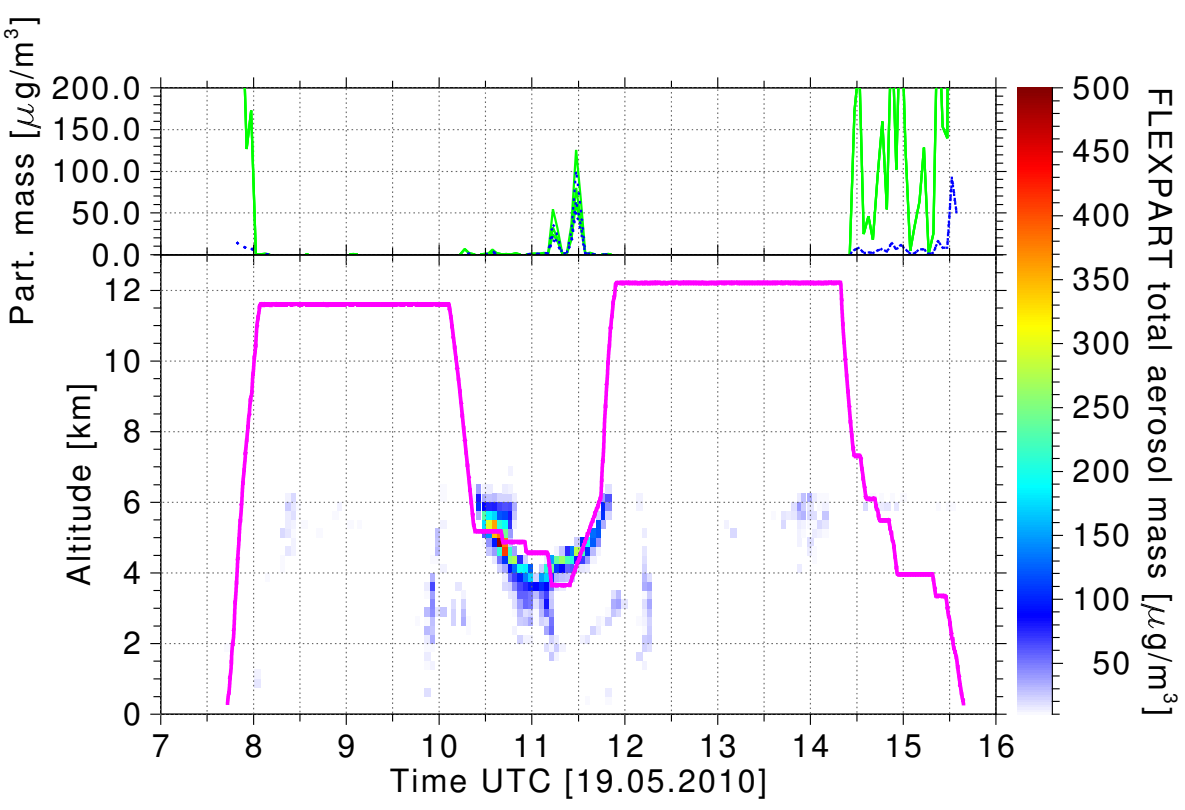

Fig. 11. Particle measurement and model comparison for flight on 19 May 2010. Upper panel: OPC total particle mass concentration for particles larger than $138 \mathrm{~nm}$ calculated with the smallest slope (solid green lines) and largest slope (dotted blue lines) in the size distribution extrapolation. The three lines are calculated assuming different refractive indices for the volcanic ash particles (see text). Lower panel: simulated vertical distribution of the ash along the CARIBIC flight track from the FLEXPART model. Same representation as in Fig. 10.

\section{Comparison to the FLEXPART dispersion model}

The FLEXPART model results (see Sect. 2.7) for the CARIBIC flight on 16 May 2010 are shown in the lower panel of Fig. 10. The total ash particle mass in all size classes is colour-coded in $\mu \mathrm{gm}^{-3}$ at ambient pressure and temperature. The CARIBIC flight altitude is indicated by the magenta line. Qualitatively the simulated volcanic aerosol concentration fits well to the CPC measurements on 16 May (upper panel of Fig. 10) with a strong peak around 10:20 UTC and a second smaller maximum around 12:00 UTC. The high CPC number densities at the end of the flight are due to low level clouds and tropospheric pollution while approaching Frankfurt airport. Since the OPC had not been working during this flight, the mass concentrations cannot be compared.

Notice that the two ash encounters simulated by FLEXPART for the CARIBIC flight on 16 May 2010 occurred in close proximity to each other and resulted from sampling the model output of a single simulated volcanic cloud, seen also by the mirrored appearance of the cloud in Fig. 10. This is the result of the aircraft turning north of Ireland around 10:15 UTC and flying back almost along the same route but at a lower altitude and shifted $\sim 14 \mathrm{~km}$ to the east (see Figs. 1 and 4). The fact that the measurements observed volcanic ash only on the return leg shows that the aircraft sampled the western edge of the volcanic cloud, which was displaced slightly further to the west by FLEXPART.

The same kind of plot is shown in the lower panel of Fig. 11 for the third CARIBIC volcano flight on
19 May 2010. The large modelled ash concentration at 10:30-10:46 UTC was not measured with the CARIBIC OPC (green lines in upper panel of Fig. 11). Only the CPCs measured a very short peak around 10:34 UTC. Considering the vertical distribution, it seems that the CARIBIC aircraft missed this volcanic cloud because it flew just above it or around it. The simulated second ash encounter at 11:1011:35 UTC fits in time to the volcanic ash observed with the CARIBIC OPC. The high OPC particle mass concentrations at the end of the flight are due to tropospheric pollution and low level clouds while flying a holding pattern north-east of Frankfurt airport and during the final approach.

The lower panel in Fig. 8 shows the simulated ash particle mass size distributions for the first (orange bars) and second (red bars) volcanic ash encounter on 19 May 2010. The error bars indicate the 1- $\sigma$ variability during the ash encounters. The size distributions qualitatively agree with the measured OPC volcanic aerosol size distribution (red \& gray bars in upper panel of Fig. 8). There is a strong increase for the size classes $250 \mathrm{~nm}, 450 \mathrm{~nm}$ and $750 \mathrm{~nm}$, similar to the size distribution measured with the OPC. For particles with diameters above $12 \mu \mathrm{m}$ (first ash encounter) and $14 \mu \mathrm{m}$ (second ash encounter), the mass size distributions decrease by nearly two orders of magnitude. These particles were present in the ash emitted by Eyjafjallajökull but settled out of the ash cloud during transport (Stohl et al., 2011).

A direct comparison of simulated and measured particle mass concentrations on 19 May is shown in Fig. 12 for the flight section 09:30-12:00 UTC. The black solid line 


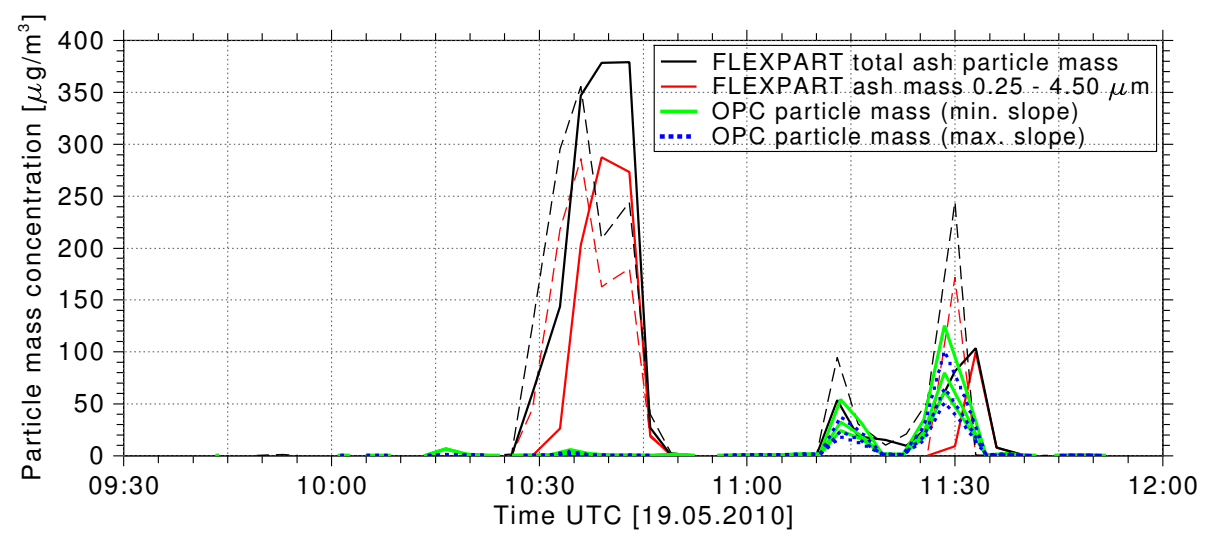

Fig. 12. Comparison of OPC measured ash concentrations with simulations from the FLEXPART model for the CARIBIC flight on 19 May 2010. The green lines indicate the particle mass concentrations derived from the OPC measurement using the smallest slope for the size distribution extrapolation (blue dotted lines using the largest slope). The three lines are calculated assuming different refractive indices for the volcanic ash particles (see text). The simulated FLEXPART total ash particle mass is shown by the black line. The red line shows the simulated FLEXPART ash particle mass in the size range $250 \mathrm{~nm}-4.5 \mu \mathrm{m}$. The black and red dashed lines show the corresponding FLEXPART ash particle masses for the altitude bin below the CARIBIC flight altitude.

shows the total volcanic aerosol concentration in all size classes from the FLEXPART simulations. The red solid line is restricted to the seven FLEXPART size classes between $250 \mathrm{~nm}$ and $4.5 \mu \mathrm{m}$ that overlap with the maximum size range of the OPC. The black and red dashed lines are the FLEXPART results for the altitude bin below the CARIBIC flight altitude. The total aerosol concentrations derived from the OPC measurements using the smallest slope for the size distribution extrapolation are shown by the green solid lines. The blue dotted lines are calculated using the largest slope (see also discussion in Sect. 4.3). Comparing OPC measurement and FLEXPART simulation, the timing of the ash clouds seems to agree slightly better for the bin below the CARIBIC flight altitude (dashed red line) while the ash mass concentration agrees best in the actual altitude bin of the model (solid red line).

The FLEXPART simulation predicts a first ash encounter during 10:35-10:45 UTC with a maximum ash concentration of $379 \mu \mathrm{gm}^{-3}\left(287 \mu \mathrm{gm}^{-3}\right.$ for particles smaller than $5 \mu \mathrm{m}$ in diameter). At that time, the OPC only measured a very small increase in the uppermost channel as indicated by the green dashed line at 10:35 UTC. This probably indicates an ash cloud that is very variable with patches of higher concentrations and patches of ash-free air. A slight error of the modelled ash cloud position and cloud edges could explain that the difference between measurement and FLEXPART model results. Later both OPC and FLEXPART simulations indicate volcanic ash with maxima around 11:13 UTC and 11:28 UTC. While the timing is very similar in OPC measurement and FLEXPART simulation for these maxima, the ash mass concentrations are somewhat different but agree within their uncertainties. The FLEXPART maximum at $11: 33 \mathrm{UTC}$ is $104 \mathrm{\mu gm}^{-3}\left(100 \mathrm{\mu gm}^{-3}\right.$ for particles smaller than $5 \mu \mathrm{m}$ ). The corresponding numbers for the OPC particle mass concentration are $133 \mu \mathrm{gm}^{-3}$ $\left(108{\mu \mathrm{gm}^{-3}}\right.$ for maximum slope) and $n=1.50-0.01$ i. Using the altitude bin below the CARIBIC flight altitude (black and red dashed lines) improves the temporal agreement but worsens the quantitative agreement. Considering the uncertainties of the measured OPC mass concentrations and the FLEXPART simulations, this is a good agreement of FLEXPART model and OPC measurements.

\section{Discussion}

The three Eyjafjallajökull volcanic flights were the first flights with the new OPC system described in this article and the first flights with the improved DOAS spectrometers (see Heue et al., 2011). Most equipment functioned well, but because of the upgrade and extension of the CARIBIC container with new or improved instruments, there were gaps in the observations. Nevertheless, the CARIBIC aircraft conducted a comprehensive suite of measurements in volcanic ash clouds of variable age during the three flights which add some unique in situ observations to the multitude of measurements collected during the Eyjafjallajökull eruption in 2010.

\subsection{Volcanic aerosol composition and concentrations}

On 20 April 2010 the volcanic ash cloud had descended from its initial altitude of $\sim 7 \mathrm{~km}$ to around $3 \mathrm{~km}$ or below over $\mathrm{Eu}-$ rope (Ansmann et al., 2010; Flentje et al., 2010). At these low altitudes the ash blended into the planetary boundary layer in which it is difficult to distinguish the normal boundary layer aerosol from volcanic ash particles. During the subsequent flights in May 2010, the volcanic clouds were found in the free troposphere well separated from the planetary boundary layer. 
The particle impactor sampler collected a total of 13 samples during the three CARIBIC volcano flights (see Table 2). Four of the samples were found to have an elemental composition rich in silicon and iron and hence were similar to ash samples collected at the surface in Iceland (see supplement of Sigmundsson et al., 2010) and to precipitation samples collected on Hohenpeißenberg in southern Germany (Flentje et al., 2010). Of those four samples the highest iron fraction was found in the sample collected on 20 April 2010 over the Baltic Sea. Silicon was enhanced in that sample as well but not as much as in the volcanic samples from the later two flights which showed silicon fractions of up to $10.0 \mathrm{wt} . \%$. Moreover the OPC observations (not shown) indicated enhanced particle concentrations only during the first part of the particle sampler integration time for the sample on 20 April. Hence, the particle sample was collected only partly in air loaded with volcanic ash but partly also in ash-free background air which did not have contact with the volcanic cloud. The aerosol elemental composition of the samples collected on 19 May 2010 over the Norwegian Sea is very similar to that found three days earlier over Northern Ireland and the Irish Sea but with a little more iron and less calcium.

Ash samples collected on the ground in the vicinity of the volcano (see details in the supplement to Sigmundsson et al. (2010)) have a similarly high $\mathrm{Si} / \mathrm{Fe}$ ratio of 3.5 as was found in the CARIBIC volcanic particle samples but have even higher relative amounts of $\mathrm{Si}, \mathrm{Ca}$ and $\mathrm{Fe}$ with $27 \mathrm{wt} . \%$, $4.1 \mathrm{wt} . \%$ and $7.6 \mathrm{wt} . \%$, respectively (see Table 2 ). The elemental composition of the aerosol samples together with the back trajectories clearly showed that the measured particles had their origin at the Eyjafjallajökull volcano on Iceland.

The decision to open or close airspace is based on measurements of the total ash mass concentration with a threshold of $4 \mathrm{mgm}^{-3}$ below which safe aircraft operation is deemed possible (European Commission, 2010). The Eyjafjallajökull eruption produced massive amounts of ash particles, around half of them being smaller than $100 \mu \mathrm{m}$ in diameter during the first days of the eruption and less later on after all the overlying ice had melted and the style of the eruption changed (Sanderson, 2010). However, single particles of $20 \mu \mathrm{m}$ diameter have a sedimentation velocity of $\sim 130$ mhour $^{-1}$ or $3.1 \mathrm{kmday}^{-1}$ (Ginoux, 2003; Schumann et al., 2011). Aggregation of particles may even lead to faster settling while aerodynamic drag on irregular particles may lead to slower sedimentation velocities (Taddeucci et al., 2011; Sorem, 1982). Hence even though there are considerable uncertainties and a large variability of the injection height of the ash, probably most of the particles $>20 \mu \mathrm{m}$ diameter were removed from the ash cloud before the CARIBIC aircraft measurements as mean transit times from emission to measurement were around $45 \mathrm{~h}$ for 16 May 2010 and around $20 \mathrm{~h}$ for 19 May. This is also confirmed by the simulated FLEXPART size distribution for 19 May in the lower panel of Fig. 8.
The optical particle counter (OPC) measures the particles size distribution up to a particle diameter of $\sim 1 \mu \mathrm{m}$ and an integral of larger particles up to the inlet cut-off $(\sim 60 \%$ collection efficiency at $5 \mu \mathrm{m}$ particle diameter). It therefore missed most of the larger particles of up to $\sim 12 \mu \mathrm{m}-14 \mu \mathrm{m}$ diameter that were still present according to the FLEXPART model even after long-range transport (lower panel in Fig. 8). Measurements with the DLR Falcon and at the Jungfraujoch research station in the Swiss Alps showed that there were indeed considerable amounts of particle mass in this size range (Schumann et al., 2011; Bukowiecki et al., 2011). Together with the unknown real size distribution for the particles larger than $1.0 \mu \mathrm{m}$ in diameter, this means that the OPC probably underestimated the true ash mass concentrations present in the ash clouds encountered during the CARIBIC volcano flights. The change in the assumed volcanic ash refractive index moves the upper detection limit of the OPC to lower particle sizes for larger real part (smaller imaginary part) of the refractive index and correspondingly all channels are shifted to smaller sizes (see red vs. gray bars in upper panel in Fig. 8). This shift to smaller diameters is the reason for the shift to lower particle mass concentrations for $n=1.60$ 0.0001 . At the same time it reduces the maximum volcanic ash mass concentration on 19 May 2010 from $133 \mu \mathrm{gm}^{-3}$ for $n=1.50-0.01$ i to $59 \mu \mathrm{gm}^{-3}$ for $n=1.60-0.0001$ i. The difference at the smallest diameters is due to different counting efficiencies at the lower detection limit of the OPC but has no significant influence on the total particle mass. The results for the intermediate refractive index fall in the middle of the two other refractive indices. The three refractive indices were selected to span the whole range of possible values. The true particle mass concentrations were therefore probably somewhere within the range calculated using the lower and upper refractive indices.

The CPC particle concentrations for the flight on 16 May (upper panel of Fig. 5) indicate new particle formation (blue line shows nucleation mode particles) at the beginning of the first volcanic cloud encounter north of Ireland around 10:17 UTC and none for the volcanic cloud around 12:00 UTC. However without knowing such important parameters as the precursor gas concentrations or the available particle surface area, it is not possible to analyse this event in more detail.

For 19 May, the three size channels of the CPC particle concentrations show differences in the shape of the peaks around 10:34 UTC, 11:15 UTC and 11:30 UTC (see arrows), especially for the nucleation mode particles (blue line in upper panel of Fig. 7). The elevated nucleation mode particle concentration indicates that a few hours before sampling the first two volcanic clouds, some new particle formation had taken place despite the elevated OPC particle mass and hence the high available particle surface area. In the last intercepted cloud around 11:30 UTC, the particle surface area was probably too large and thus inhibited new particle formation. This explanation is supported by the anti-correlation of $\mathrm{N}_{12}$ (red 
line) and OPC particle mass (green lines). For the OPC mass concentration, the peak around 11:30 UTC is highest while $\mathrm{N}_{12}$ is largest for the first peak around 10:34 UTC. This indicates a consecutive shift towards larger particles because already a few more large particles lead to a strong increase of the particle mass as it depends on the radius cubed.

\subsection{Trace gases in the volcanic clouds}

The CO measurements showed increases of up to $80 \mathrm{ppb}$ in some parts of the volcanic clouds and no increases in other parts where the CPC and OPC measurements clearly showed that the aircraft was still inside the volcanic cloud. This demonstrates the large variability of the volcanic clouds which is probably due to the changing emission characteristics combined with small-scale structures created by mixing and turbulence during the advection of the volcanic clouds from Iceland to the British Isles and the Norwegian Sea.

A plume of Iceland's Hekla volcano was shown to contain up to 45 ppbv CO about $34 \mathrm{~h}$ after the eruption (Rose et al., 2006). The DLR Falcon found CO enhancements of up to 72 ppb in one Eyjafjallaökull ash cloud on 2 May 2010 but much less in most other observed volcanic clouds (Schumann et al., 2011). The CARIBIC measurements for the Eyjafjallajökull clouds were made far away from the volcano after $19 \mathrm{~h}-53 \mathrm{~h}$ of transport and mixing. Compared to these other measurements, the observed $\mathrm{CO}$ enhancements of up to $80 \mathrm{ppb}$ are comparable but rather high while the $\mathrm{CO}$ variability agrees with the DLR Falcon measurements. Production of $\mathrm{CO}$ through the reaction of methane with chlorine radicals $(\mathrm{Cl})$, shown to be present in the volcanic clouds, cannot explain the observed $\mathrm{CO}$ peaks. At the derived $\mathrm{Cl}$ concentrations, the transport time of up to two days would at most produce a few ppb of CO. As strongly enhanced hydroxyl radicals $(\mathrm{OH})$ inside the volcanic clouds are found to be very unlikely (Baker et al., 2011), the production of CO through methane destruction by $\mathrm{OH}$ also fails to provide an explanation for the observed $\mathrm{CO}$ peaks. For the flight on 16 May 2010, the CO enhancement together with the indications for new particle formation from the CPC measurements imply that deep convection of boundary layer air at the volcano may have contributed to the enhanced $\mathrm{CO}$ concentrations.

During the second CARIBIC volcano flight on 16 May 2010, no significant ozone decreases were found during the $\mathrm{CO}$ peaks. On 19 May, two co-located $\mathrm{O}_{3}$ dips were found around 11:28 UTC (see lower panel of Fig. 7). However, considering the ozone variability before and after the encounter of volcanic air, it remains unclear whether this is due to $\mathrm{O}_{3}$ destruction in the volcanic clouds or just the background variability.

Vance et al. (2010) found a mean $\mathrm{O}_{3}$ destruction of $37 \%$ in Eyjafjallajökull clouds that was maintained for several days after the eruption. Even larger $\mathrm{O}_{3}$ depletions were found by the DLR Falcon (Schumann et al., 2011). Both findings are in agreement with model calculations by von Glasow (2010) and rapid $\mathrm{O}_{3}$ destruction in a volcanic cloud after chlorine and bromine activation in the stratosphere reported by Millard et al. (2006). In the model, the $\mathrm{O}_{3}$ loss is mostly due to bromine chemistry. The CARIBIC NMHC measurements inside the volcanic clouds could not identify bromine chemistry but instead showed clear indications of chlorine chemistry (Baker et al., 2011). The latter can also destroy $\mathrm{O}_{3}$ but did so in the model with less efficiency. Also there is much more $\mathrm{O}_{3}(60 \mathrm{ppb})$ than $\mathrm{BrO}(6 \mathrm{ppt})$. This may explain the absence of clear $\mathrm{O}_{3}$ losses inside the volcanic clouds measured during the CARIBIC flights. A detailed discussion of the MAX-DOAS $\mathrm{SO}_{2}$ and $\mathrm{BrO}$ measurements on 16 May and comparisons of MAX-DOAS and satellite measurements has been published in a companion article in this special issue by Heue et al. (2011).

The clearer volcanic signature in the NMHC depletions on 19 May 2010 compared to 16 May may be due to the shorter mean transport times of $\sim 20 \mathrm{~h}$ for the third flight on 19 May compared to $\sim 45 \mathrm{~h}$ for the second flight thus giving less opportunity for mixing with non-volcanic air. However, as the NMHC background values were nearly identical during these two flights and it seems highly unlikely that the volcano is an NMHC source, it could still be that the volcanic emission was stronger with more available chlorine for the later flight. A more detailed analysis of the NMHC depletions detection during the three CARIBIC volcano flights has been published in a separate article by Baker et al. (2011).

The partial mismatch of chemical influence (as indicated in the whole air samples) and ash particle detection during the flight on 16 May 2010 over Northern Ireland and on 19 May over the Norwegian Sea shows a partial separation of volcanic ash and volcanic gases, presumable already close to the volcano eruption column (Holasek et al., 1996), with subsequent somewhat different dispersion due to wind shear. This also means that glazing of aircraft turbines by melting ash and abrasion of aircraft windows does not necessarily occur in the same airspace where enhanced corrosion may occur due to sulphuric acid formed when volcanic $\mathrm{SO}_{2}$ reacts with atmospheric water. The separation of volcanic ash particles and volcanic gases is confirmed by satellite investigations of the Eyjafjallajökull eruption (Thomas and Prata, 2011).

\subsection{Comparison to FLEXPART dispersion model}

Although forecasts from the Volcanic Ash Advisory Centre (VAAC) in London as well as multiple other dispersion models were used for the flight route planning ahead of the flights, it appeared to be generally difficult to intercept parts of the diluted volcanic clouds, in particular in view of the limited vertical extent of the ash layers. The VAAC forecasts proved to be useful to find the general area of ash contamination while other models like the NILU FLEXPART model proved to be more useful to determine the flight altitude 
due to their higher vertical resolution. The comparisons of CARIBIC measurements and FLEXPART aerosol modelling show good agreement for some parts of the clouds while the position of the cloud edges was not always well simulated. This is an encouraging result given that the CARIBIC particle mass concentration measurements have their own set of uncertainties mainly due to the unknown refractive index and the restricted size range covered by the OPC (see Sect. 2.2).

This differences between CARIBIC measurements and FLEXPART ash dispersion modelling show that even with a well-constrained source term (see detailed description of the model run in Stohl et al., 2011) simulated volcanic clouds can be offset from real cloud locations due to errors still present in the source term, uncertainties in the simulated transport and ash removal processes. It also indicates the continued need for a safety zone around modelled ash clouds with concentrations exceeding thresholds considered safe for aviation, to allow for ash cloud position errors.

\section{Conclusions}

The CARIBIC observatory is designed for the regular surveillance of the atmosphere and the measurement equipment was not optimised for the detection and investigation of volcanic ash and gas clouds. However, the shear lack of information following the eruption of the Eyjafjallajökull in April 2010 lead to the decision to conduct three special CARIBIC flights on 20 April over the Baltic Sea and Sweden, on 16 May over Ireland and the Irish Sea and on 19 May 2010 over the Norwegian Sea. They proved that CARIBIC can investigate many different aspects of volcanic clouds (see also Heue et al., 2011; Baker et al., 2011; Martinsson et al., 2009). The CARIBIC container features a multitude of instruments for both in situ sampling and remote sensing as well as air and particle sampling for post-flight laboratory analyses.

Aerosol particles collected over the Baltic Sea on 20 April 2010 indicated the presence of volcanic ash through their elemental composition with an enhancement in silicon and a very high enhancement in iron, similar to ash samples collected on the ground close to the volcano. Even larger relative enhancements of silicon, titanium and calcium were found in particle samples collected over the Irish Sea on 16 May and the Norwegian Sea on 19 May showing that the aircraft really sampled inside volcanic clouds from the Eyjafjallajökull volcano. This is also supported by the calculated backward trajectories starting at the CARIBIC flight tracks as well as by the whole air samples and the particle counters. A comparison of the Eyjafjallajökull volcanic ash particle samples with other volcanic samples collected by CARIBIC will be published elsewhere (see Andersson and Martinsson, 2012).
The optical particle counter showed enhanced concentrations of particles with diameters larger than $400 \mathrm{~nm}$ on 19 May 2010 over the Norwegian Sea in regions where FLEXPART and other dispersion models had predicted the occurrence of volcanic ash from the Eyjafjallajökull volcano. A few aerosol mass concentration peaks were also found on 20 April. The highest aerosol mass concentration found was

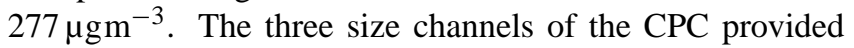
signs of new particle formation in the volcanic clouds and suppression of new particle formation at the largest particle mass and hence particle surface concentrations. The comparison of FLEXPART simulations and CARIBIC particle mass measurements shows that for improving the ash dispersion model forecasts, it will be important to measure as close to the source as possible and with instruments that cover the entire size range of the ash particles.

On 16 May 2010, $\mathrm{SO}_{2}$ clouds were found over Northern Ireland and the Irish Sea together with smaller enhancements of BrO. Non-methane hydrocarbon (NMHC) measurements in whole air samples collected on 16 May and 19 May showed a depletion pattern that was dominated by chlorine radical chemistry. The observed $\mathrm{CO}$ enhancements of up to $80 \mathrm{ppb}$ were larger than expected from NMHC destruction as strongly enhanced hydroxyl concentrations could also be excluded from the NMHC measurements (Baker et al., 2011). No significant ozone depletions were found in the volcanic clouds.

Based on the CARIBIC observations, three key points should be taken into consideration for aircraft safety in the event of a volcanic eruption. First, agreement between observations and model predictions shows that models work well to gain an approximate location of volcanic ash. However, discrepancies indicate the need for a safety buffer zone around modelled ash clouds with high ash mass concentrations. Second, CARIBIC measurements indicate that areas of high concentrations of potentially corrosive volcanic gases (like $\mathrm{SO}_{2}$, see Casadevall, 1993) are not always coincident with areas having enhanced particle densities (Thomas and Prata, 2011). Third, for a better understanding of volcanic clouds, comprehensive measurements as those with the CARIBIC container offer a detailed insight into their particle number and mass densities, trace gases and the chemistry inside these clouds.

Acknowledgements. We wish to thank all our CARIBIC partners. Lufthansa and Lufthansa Technik enable and support CARIBIC. Fraport supports CARIBIC financially. We especially acknowledge T. Dauer, A. Waibel and our first officer during the volcano flights M. Hoell. We particularly wish to thank D. Scharffe, S. Weber and C. Koeppel for their continued work and dedication to the development and deployment of the container system and for preparing it on short notice for the volcano flights. We acknowledge the ECMWF meteorological data obtained via KNMI and their use for the FLEXPART model runs at NILU. We also wish to thank K. Sturm and U. Busch at the German Weather Service (DWD), 
the EURAD modelling group at the University of Cologne and the Finnish Meteorological Institute (SILAM model) for help during the flight planning as well as U. Schumann (DLR) for useful discussions and advice.

The service charges for this open access publication have been covered by the Max Planck Society.

Edited by: G. Pappalardo

\section{References}

Airbus Customer Services: Getting to grips with aircraft performance, Tech. rep., Airbus S.A.S., Blagnac, France, 2002.

Andersson, S. and Martinsson, B.: Composition and evolution of volcanic aerosol following three eruptions 2008-2010, in preparation, 2012.

Ansmann, A., Tesche, M., Groß, S., Freudenthaler, V., Seifert, P., Hiebsch, A., Schmidt, J., Wandinger, U., Mattis, I., Müller, D., and Wiegner, M.: The 16 April 2010 major volcanic ash plume over central Europe: EARLINET lidar and AERONET photometer observations at Leipzig and Munich, Germany, Geophys. Res. Lett., 37, L13810, doi:10.1029/2010GL043809, 2010.

Ansmann, A., Tesche, M., Seifert, P., Groß, S., Freudenthaler, V., Apituley, A., Wilson, K. M., Serikov, I., Linné, H., Heinold, B., Hiebsch, A., Schnell, F., Schmidt, J., Mattis, I., Wandinger, U., and Wiegner, M.: Ash and finemode particle mass profiles from EARLINET-AERONET observations over central Europe after the eruptions of the Eyjafjallajökull volcano in 2010, J. Geophys. Res., 116, D00U02, doi:10.1029/2010JD015567, 2011.

Baker, A. K., Slemr, F., and Brenninkmeijer, C. A. M.: Analysis of non-methane hydrocarbons in air samples collected aboard the CARIBIC passenger aircraft, Atmos. Meas. Tech., 3, 311-321, doi:10.5194/amt-3-311-2010, 2010.

Baker, A. K., Rauthe-Schöch, A., Schuck, T. J., Brenninkmeijer, C. A. M., van Velthoven, P. F. J., Wisher, A., and Oram, D. E.: Investigation of chlorine radical chemistry in the Eyjafjallajökull volcanic plume using observed depletions in non-methane hydrocarbons, Geophys. Res. Lett., 38, L13801, doi:10.1029/2011GL047571, 2011.

Bond, T. C. and Bergstrom, R. W.: Light absorption by carbonaceous particles: An investigative review, Aerosol Sci. Tech., 40, 27-67, doi:10.1080/02786820500421521, 2006.

Brenninkmeijer, C. A. M., Crutzen, P., Boumard, F., Dauer, T., Dix, B., Ebinghaus, R., Filippi, D., Fischer, H., Franke, H., Frieß, U., Heintzenberg, J., Helleis, F., Hermann, M., Kock, H. H., Koeppel, C., Lelieveld, J., Leuenberger, M., Martinsson, B. G., Miemczyk, S., Moret, H. P., Nguyen, H. N., Nyfeler, P., Oram, D., O’Sullivan, D., Penkett, S., Platt, U., Pupek, M., Ramonet, M., Randa, B., Reichelt, M., Rhee, T. S., Rohwer, J., Rosenfeld, K., Scharffe, D., Schlager, H., Schumann, U., Slemr, F., Sprung, D., Stock, P., Thaler, R., Valentino, F., van Velthoven, P., Waibel, A., Wandel, A., Waschitschek, K., Wiedensohler, A., Xueref-Remy, I., Zahn, A., Zech, U., and Ziereis, H.: Civil aircraft for the regular investigation of the atmosphere based on an instrumented container: The new CARIBIC system, Atmos. Chem. Phys., 7, 4953-4976, doi:10.5194/acp-7-4953-2007, 2007.

Bukowiecki, N., Zieger, P., Weingartner, E., Jurányi, Z., Gysel, M., Neininger, B., Schneider, B., Hueglin, C., Ulrich, A., Wichser,
A., Henne, S., Brunner, D., Kaegi, R., Schwikowski, M., Tobler, L., Wienhold, F. G., Engel, I., Buchmann, B., Peter, T., and Baltensperger, U.: Ground-based and airborne in-situ measurements of the Eyjafjallajökull volcanic aerosol plume in Switzerland in spring 2010, Atmos. Chem. Phys., 11, 10011-10030, doi:10.5194/acp-11-10011-2011, 2011.

Casadevall, T. J.: Volcanic hazards and aviation safety: Lessons of the past decade, Flight Safety Foundation - Flight Safety Digest, $1-9,1993$.

Dibb, J. E., Talbot, R. W., Scheuer, E. M., Blake, D. R., Blake, N. J., Gregory, G. L., Sachse, G. W., and Thornton, D.: Aerosol chemical composition and distribution during the Pacific Exploratory Mission (PEM) Tropics, J. Geophys. Res., 104, 57855800, doi:10.1029/1998JD100001, 1999.

Dick, W. D., Ziemann, P. J., and McMurry, P. H.: Multiangle light-scattering measurements of refractive index of submicron atmospheric particles, Aerosol Sci. Technol., 41, 549-569, doi:10.1080/02786820701272012, 2007.

Dix, B., Brenninkmeijer, C. A. M., Frieß, U., Wagner, T., and Platt, U.: Airborne multi-axis DOAS measurements of atmospheric trace gases on CARIBIC long-distance flights, Atmos. Meas. Tech., 2, 639-652, doi:10.5194/amt-2-639-2009, 2009.

Emeis, S., Forkel, R., Junkermann, W., Schäfer, K., Flentje, H., Gilge, S., Fricke, W., Wiegner, M., Freudenthaler, V., Groß, S., Ries, L., Meinhardt, F., Birmili, W., Münkel, C., Obleitner, F., and Suppan, P.: Measurement and simulation of the 16/17 April 2010 Eyjafjallajökull volcanic ash layer dispersion in the northern Alpine region, Atmos. Chem. Phys., 11, 26892701, doi:10.5194/acp-11-2689-2011, 2011.

European Commission: "Volcano crisis report": Report on the actions undertaken in the context of the impact of the volcanic ash cloud crisis on the air transport industry, Tech. rep., European Union, available online at: http://ec.europa.eu/transport/ ash_cloud_crisis_en.htm, 2010.

Flentje, H., Claude, H., Elste, T., Gilge, S., Köhler, U., PlassDülmer, C., Steinbrecht, W., Thomas, W., Werner, A., and Fricke, W.: The Eyjafjallajökull eruption in April 2010 - Detection of volcanic plume using in-situ measurements, ozone sondes and lidar-ceilometer profiles, Atmos. Chem. Phys., 10, 1008510092, doi:10.5194/acp-10-10085-2010, 2010.

Fortuin, J. P. F. and Kelder, H.: An ozone climatology based on ozonesonde and satellite measurements, J. Geophys. Res., 103, 31709-31734, doi:10.1029/1998JD200008, 1998.

Froyd, K. D., Murphy, D. M., Sanford, T. J., Thomson, D. S., Wilson, J. C., Pfister, L., and Lait, L.: Aerosol composition of the tropical upper troposphere, Atmos. Chem. Phys., 9, 4363-4385, doi:10.5194/acp-9-4363-2009, 2009.

Gasteiger, J., Groß, S., Freudenthaler, V., and Wiegner, M.: Volcanic ash from Iceland over Munich: Mass concentration retrieved from ground-based remote sensing measurements, Atmos. Chem. Phys., 11, 2209-2223, doi:10.5194/acp-11-22092011, 2011.

Gertisser, R.: Eyjafjallajökull volcano causes widespread disruption to European air traffic, Geology Today, 26, 94-95, doi:10.1111/j.1365-2451.2010.00757.x, 2010.

Ginoux, P.: Effects of nonsphericity on mineral dust modeling, J. Geophys. Res., 108, 4052, doi:10.1029/2002JD002516, 2003.

Gíslason, S. R. and Alfredsson, H. A.: Travelogue: Sampling the volcanic ash from the Eyjafjallajökull volcano, Iceland - A per- 
sonal account, Elements, 6, 269-270, 2010.

Gudmundsson, M. T., Vogfjörd, K., Thorbjarnardóttir, B., Roberts, M. J., Pedersen, R., and Jakobsdóttir, S.: Eruptions of Eyjafjallajökull volcano, Iceland, Trans. Am. Geophys. Union (EOS), 91, 190-191, doi:10.1029/2010EO210002, 2010.

Hermann, M. and Wiedensohler, A.: Counting efficiency of condensation particle counters at low-pressures with illustrative data from the upper troposphere, J. Aerosol Sci., 32, 975-991, doi:10.1016/S0021-8502(01)00037-4, 2001.

Heue, K.-P., Brenninkmeijer, C. A. M., Wagner, T., Mies, K., Dix, B., Frieß, U., Martinsson, B. G., Slemr, F., and van Velthoven, P. F. J.: Observations of the 2008 Kasatochi volcanic $\mathrm{SO}_{2}$ plume by CARIBIC aircraft DOAS and the GOME-2 satellite, Atmos. Chem. Phys., 10, 4699-4713, doi:10.5194/acp-10-4699-2010, 2010.

Heue, K.-P., Brenninkmeijer, C. A. M., Baker, A. K., RautheSchöch, A., Walter, D., Wagner, T., Hörmann, C., Sihler, H., Dix, B., Frieß, U., Platt, U., Martinsson, B. G., van Velthoven, P. F. J., Zahn, A., and Ebinghaus, R.: $\mathrm{SO}_{2}$ and $\mathrm{BrO}$ observation in the plume of the Eyjafjallajökull volcano 2010: CARIBIC and GOME-2 retrievals, Atmos. Chem. Phys., 11, 2973-2989, doi:10.5194/acp-11-2973-2011, 2011.

Holasek, R. E., Woods, A. W., and Self, S.: Experiments on gasash separation processes in volcanic umbrella plumes, J. Volcanology \& Geotherm. Res., 70, 169-181, doi:10.1016/03770273(95)00054-2, 1996.

Hummel, J. R., Shettle, E. P., and Longtin, D. R.: A new background stratospheric aerosol model for use in atmospheric radiation models, Tech. Rep. AFGL-TR-88-0166, Air Force Geophysics Laboratory, Hanscom AFB, MA, USA, ADA210110, 1988.

Jenkins, S.: Observations of the Eyjafjallajökull eruption, http://www.carl.co.uk/downloads/Icelanderuption.pdf, last access 9 March 2011, 2010.

Kojima, T., Buseck, P. R., Wilson, J. C., Reeves, J. M., and Mahoney, M. J.: Aerosol particles from tropical convective systems: Cloud tops and cirrus anvils, J. Geophys. Res., 109, D12201, doi:10.1029/2003JD004504, 2004.

Korolev, A. V., Emery, E. F., Strapp, J. W., Cober, S. G., Isaac, G. A., Wasey, M., and Marcotte, D.: Small ice particle observations in tropospheric clouds: Fact or artifact? Airborne Icing Instrumentation Evaluation Experiment, B. Am. Meteorol. Soc., 92, 967-973, doi:10.1175/2010BAMS3141.1, 2011.

Krekov, G. M.: Models of atmospheric aerosols, in: Aerosol effects on climate, edited by Jennings, S. G., 37-41, The University of Arizona Press, 1993.

Kulkarni, P., Baron, P. A., and Willeke, K. (eds.): Aerosol measurement - Principles, techniques, and applications, John Wiley \& Sons, Hoboken, NJ, USA, 3 edn., 2011

Martinsson, B. G., Brenninkmeijer, C. A. M., Carn, S. A., Hermann, M., Heue, K.-P., van Velthoven, P. F. J., and Zahn, A.: Influence of the 2008 Kasatochi volcanic eruption on sulfurous and carbonaceous aerosol constituents in the lower stratosphere, Geophys. Res. Lett., 36, L12813, doi:10.1029/2009GL038735, 2009.

Marzano, F. S., Lamantea, M., Montopoli, M., Di Fabio, S., and Picciotti, E.: The Eyjafjöll explosive volcanic eruption from a microwave weather radar perspective, Atmos. Chem. Phys., 11, 9503-9518, doi:10.5194/acp-11-9503-2011, 2011.
Millard, G. A., Mather, T. A., Pyle, D. M., Rose, W. I., and Thornton, B.: Halogen emissions from a small volcanic eruption: Modeling the peak concentrations, dispersion, and volcanically induced ozone loss in the stratosphere, Geophys. Res. Lett., 33, L19815, doi:10.1029/2006GL026959, 2006.

Mona, L., Amodeo, A., D’Amico, G., Giunta, A., Madonna, F., and Pappalardo, G.: Multi-wavelength Raman lidar observations of the Eyjafjallajökull volcanic cloud over Potenza, Southern Italy, Atmos. Chem. Phys. Discuss., 11, 12763-12803, doi:10.5194/acpd-11-12763-2011, 2011.

Morgan, W. T., Allan, J. D., Bower, K. N., Capes, G., Crosier, J., Williams, P. I., and Coe, H.: Vertical distribution of sub-micron aerosol chemical composition from North-Western Europe and the North-East Atlantic, Atmos. Chem. Phys., 9, 5389-5401, doi:10.5194/acp-9-5389-2009, 2009.

Murphy, D. M., Cziczo, D. J., Hudson, P. K., and Thomson, D. S.: Carbonaceous material in aerosol particles in the lower stratosphere and tropopause region, J. Geophys. Res., 112, D04203, doi:10.1029/2006JD007297, 2007.

Newhall, C. G. and Self, S.: The Volcanic Explosivity Index (VEI): An estimate of explosive magnitude for historical volcanism, J. Geophys. Res., 87, 1231-1238, doi:10.1029/JC087iC02p01231, 1982.

Nguyen, H. N. and Martinsson, B. G.: Analysis of C, N and O in aerosol collected on an organic backing using internal blank measurements and variable beam size, Nucl. Inst. \& Meth. in Phys. Res., 264, 96-102, doi:10.1016/j.nimb.2007.08.001, 2007.

Nguyen, H. N., Gudmundsson, A., and Martinsson, B. G.: Design and calibration of a multi-channel aerosol sampler for tropopause region studies from the CARIBIC platform, Aerosol Sci. Tech., 40, 649-655, doi:10.1080/02786820600767807, 2006.

Nguyen, H. N., Martinsson, B. G., Wagner, J. B., Carlemalm, E., Ebert, M., Weinbruch, S., Brenninkmeijer, C. A. M., Heintzenberg, J., Hermann, M., Schuck, T., van Velthoven, P. F. J., and Zahn, A.: Chemical composition and morphology of individual aerosol particles from a CARIBIC flight at $10 \mathrm{~km}$ altitude between $50^{\circ} \mathrm{N}$ and $30^{\circ} \mathrm{S}$, J. Geophys. Res., 113, D23209, doi:10.1029/2008JD009956, 2008.

O'Sullivan, D. A.: Temporal and spatial variability of halogenated compounds and other trace gases, Ph.D. thesis, University of East Anglia, Norwich, UK, 2007.

Petersen, G. N.: A short meteorological overview of the Eyjafjallajökull eruption 14 April-23 May 2010, Weather, 65, 203-207, doi:10.1002/wea.634, 2010.

Pietruczuk, A., Krzyścin, J. W., Jarosławski, J., Podgórski, J., Sobolewski, P., and Wink, J.: Eyjafjallajökull volcano ash observed over Belsk $\left(52^{\circ} \mathrm{N}, 21^{\circ} \mathrm{E}\right)$, Poland, in April 2010, Int. J. Remote Sens., 31, 3981-3986, doi:10.1080/01431161.2010.498030, 2010.

Prata, A. J. and Tupper, A.: Aviation hazards from volcanoes: The state of the science, Nat. Hazards, 51, 239-244, doi:10.1007/s11069-009-9415-y, 2009.

Pratt, K. A. and Prather, K. A.: Aircraft measurements of vertical profiles of aerosol mixing states, J. Geophys. Res., 115, D11305, doi:10.1029/2009JD013150, 2010.

Rose, W. I., Millard, G. A., Mather, T. A., Hunton, D. E., Anderson, B., Oppenheimer, C., Thornton, B. F., Gerlach, T. M., Viggiano, A. A., Kondo, Y., Miller, T. M., and Ballenthin, J. O.: Atmospheric chemistry of a 33-34 hour old volcanic cloud from Hekla 
Volcano (Iceland): Insights from direct sampling and the application of chemical box modeling, J. Geophys. Res., 111, D20206, doi:10.1029/2005JD006872, 2006.

Sanderson, K.: Out of the ashes, Nature, 465, 544-545, doi:10.1038/465544a, 2010.

Schäfer, K., Thomas, W., Peters, A., Ries, L., Obleitner, F., Schnelle-Kreis, J., Birmili, W., Diemer, J., Fricke, W., Junkermann, W., Pitz, M., Emeis, S., Forkel, R., Suppan, P., Flentje, H., Gilge, S., Wichmann, H. E., Meinhardt, F., Zimmermann, R., Weinhold, K., Soentgen, J., Münkel, C., Freuer, C., and Cyrys, J.: Influences of the 2010 Eyjafjallajökull volcanic plume on air quality in the northern Alpine region, Atmos. Chem. Phys., 11, 8555-8575, doi:10.5194/acp-11-8555-2011, 2011.

Scharffe, D., Slemr, F., Brenninkmeier, C. A. M., and Zahn, A.: Carbon monoxide measurements onboard the CARIBIC aircraft using UV resonance fluorescence, in preparation, 2012.

Scheele, M. P., Siegmund, P. C., and van Velthoven, P. F. J.: Sensitivity of trajectories to data resolution and its dependence on the starting point: In or outside a tropopause fold, Meteorol. Appl., 3, 267-273, doi:10.1002/met.5060030308, 1996.

Schuck, T. J., Brenninkmeijer, C. A. M., Slemr, F., Xueref-Remy, I., and Zahn, A.: Greenhouse gas analysis of air samples collected onboard the CARIBIC passenger aircraft, Atmos. Meas. Tech., 2, 449-464, doi:10.5194/amt-2-449-2009, 2009.

Schumann, U., Weinzierl, B., Reitebuch, O., Schlager, H., Minikin, A., Forster, C., Baumann, R., Sailer, T., Graf, K., Mannstein, H., Voigt, C., Rahm, S., Simmet, R., Scheibe, M., Lichtenstern, M., Stock, P., Rüba, H., Schäuble, D., Tafferner, A., Rautenhaus, M., Gerz, T., Ziereis, H., Krautstrunk, M., Mallaun, C., Gayet, J.-F., Lieke, K., Kandler, K., Ebert, M., Weinbruch, S., Stohl, A., Gasteiger, J., Groß, S., Freudenthaler, V., Wiegner, M., Ansmann, A., Tesche, M., Olafsson, H., and Sturm, K.: Airborne observations of the Eyjafjalla volcano ash cloud over Europe during air space closure in April and May 2010, Atmos. Chem. Phys., 11, 2245-2279, doi:10.5194/acp-11-2245-2011, 2011.

Schwarz, J. P., Gao, R. S., Fahey, D. W., Thomson, D. S., Watts, L. A., Wilson, J. C., Reeves, J. M., Darbeheshti, M., Baumgardner, D. G., Kok, G. L., Chung, S. H., Schulz, M., Hendricks, J., Lauer, A., Kärcher, B., Slowik, J. G., Rosenlof, K. H., Thompson, T. L., Langford, A. O., Loewenstein, M., and Aikin, K. C.: Single-particle measurements of midlatitude black carbon and light-scattering aerosols from the boundary layer to the lower stratosphere, J. Geophys. Res., 111, D16207, doi:10.1029/2006JD007076, 2006.

Schwarz, J. P., Spackman, J. R., Gao, R. S., Watts, L. A., Stier, P., Schulz, M., Davis, S. M., Wofsy, S. C., and Fahey, D. W.: Global-scale black carbon profiles observed in the remote atmosphere and compared to models, Geophys. Res. Lett., 37, L18812, doi:10.1029/2010GL044372, 2010.

Shoji, S., Nanzyo, M., and Dahlgren, R.: Volcanic ash soils: Genesis, properties and utilization, Developments in Soil Science, Elsevier Science Publishers B.V., Amsterdam, The Netherlands, p. 108, 1994.

Sigmundsson, F., Hreinsdóttir, S., Hooper, A., Árnadóttir, T., Pedersen, R., Roberts, M. J., Óskarsson, N., Auriac, A., Decriem, J., Einarsson, P., Geirsson, H., Hensch, M., Ófeigsson, B. G., Sturkell, E., Sveinbjörnsson, H., and Feigl, K. L.: Intrusion triggering of the 2010 Eyjafjallajökull explosive eruption, Nature, 468, 426-430, doi:10.1038/nature09558, 2010.
Sorem, R. K.: Volcanic ash clusters: Tephra rafts and scavengers, J. Volcanology \& Geotherm. Res., 13, 63-71, doi:10.1016/03770273(82)90019-1, 1982.

Stohl, A., Haimberger, L., Scheele, M. P., and Wernli, H.: An intercomparison of results from three trajectory models, Meteorol. Appl., 8, 127-135, doi:10.1017/S1350482701002018, 2001.

Stohl, A., Forster, C., Frank, A., Seibert, P., and G.Wotawa: Technical note: The Lagrangian particle dispersion model FLEXPART version 6.2, Atmos. Chem. Phys., 5, 2461-2474, doi:10.5194/acp-5-2461-2005, 2005.

Stohl, A., Prata, A. J., Eckhardt, S., Clarisse, L., Durant, A., Henne, S., Kristiansen, N. I., Minikin, A., Schumann, U., Seibert, P., Stebel, K., Thomas, H. E., Thorsteinsson, T., Tørseth, K., and Weinzierl, B.: Determination of time- and height-resolved volcanic ash emissions and their use for quantitative ash dispersion modeling: The 2010 Eyjafjallajökull eruption, Atmos. Chem. Phys., 11, 4333-4351, doi:10.5194/acp-11-4333-2011, 2011.

Sturkell, E., Einarsson, P., Sigmundsson, F., Hooper, A., Ófeigsson, B. G., Geirsson, H., and Ólafsson, H.: Katla and Eyjafjallajökull volcanoes, in: The Mýrdalsjokull ice cap, Iceland - Glacial processes, sediments and landforms on an active volcano, edited by: Schomacker, A., Krüger, J., and Kjaer, K., vol. 13 of Developments in Quaternary Science, 5-21, doi:10.1016/S15710866(09)01302-5, 2009.

Taddeucci, J., Scarlato, P., Montanaro, C., Cimarelli, C., Del Bello, E., Freda, C., Andronico, D., Gudmundsson, M. T., and Dingwell, D. B.: Aggregation-dominated ash settling from the Eyjafjallajökull volcanic cloud illuminated by field and laboratory high-speed imaging, Geology, 39, 891-894, doi:10.1130/G32016.1, 2011.

Thomas, H. E. and Prata, A. J.: Sulphur dioxide as a volcanic ash proxy during the April-May 2010 eruption of Eyjafjallajökull volcano, Iceland, Atmos. Chem. Phys., 11, 6871-6880, doi:10.5194/acp-11-6871-2011, 2011.

Toon, O. B., Pollack, J. B., and Khare, B. N.: The optical constants of several atmospheric aerosol species: ammonium sulfate, aluminum oxide, and sodium chloride, J. Geophys. Res., 81, 57335748, doi:10.1029/JC081i033p05733, 1976.

van Velthoven, P. F. J.: Meteorological analysis of CARIBIC, http:// www.knmi.nl/samenw/campaign_support/CARIBIC/, last access 9 January 2012, 2012.

Vance, A., McGonigle, A. J. S., Aiuppa, A., Stith, J. L., Turnbull, K., and von Glasow, R.: Ozone depletion in tropospheric volcanic plumes, Geophys. Res. Lett., 37, L22802, doi:10.1029/2010GL044997, 2010.

von Glasow, R.: Atmospheric chemistry in volcanic plumes, Proc. Nat. Acad. Sci. USA, 107, 6594-6599, doi:10.1073/pnas.0913164107, 2010.

Weigelt, A.: Global scale routinely measurement of the particle size distribution in the UT/LS region, Ph.D. thesis, Universität Leipzig, Leipzig, Germany, in preparation, 2012.

Wiegner, M., Gasteiger, J., Groß, S., Schnell, F., Freudenthaler, V., and Forkel, R.: Characterization of the Eyjafjallajökull ashplume: Potential of lidar remote sensing, Phys. Chem. Earth, doi:10.1016/j.pce.2011.01.006, in press, 2011.

Zahn, A., Weppner, J., Widmann, H., Schlote-Holubek, K., Burger, B., Kühner, T., and Franke, H.: A fast and precise chemiluminescence ozone detector for eddy flux and airborne application, Atmos. Meas. Tech. Disc., 4, 6539-6575, doi:10.5194/amtd-4- 
6539-2011, 2011.

Zimanowski, B., Büttner, R., Lorenz, V., and Häfele, H.-G.: Fragmentation of basaltic melt in the course of explosive volcanism, J. Geophys. Res., 102, 803-814, doi:10.1029/96JB02935, 1997.
Zimanowski, B., Wohletz, K., Dellino, P., and Büttner, R.: The volcanic ash problem, J. Volcanology \& Geotherm. Res., 122, 1-5, doi:10.1016/S0377-0273(02)00471-7, 2003. 